\title{
Profiles of katabatic flow in summer and winter over Coats Land, Antarctica
}

\author{
By IAN A. RENFREW* and PHILIP S. ANDERSON \\ British Antarctic Survey, Cambridge, UK
}

(Received 11 July 2005; revised 17 October 2005)

\section{SUMMARY}

Observations from a novel autonomous Doppler sodar wind profiling system are described and analysed. These include the first continuous wintertime soundings of katabatic winds over Antarctica-a continent with which they are synonymous. During 2002 and 2003 over 2600 wind profiles were taken during 'case-studies' of high-resolution sounding lasting hours to days. These case-studies have been subjectively classified as: synoptically driven, katabatically influenced (28 days); primarily katabatically driven flows (a subset of 16 days); or other flow types. The Doppler sodar observations were augmented by automatic weather station observations at the field site and further up the slope, as well as synoptic and upper-air observations at Halley Research Station, some $50 \mathrm{~km}$ distant on the Brunt Ice Shelf.

In primarily katabatic flows there is a systematic change in the shape and depth of the low-level katabatic jet with wind speed. Relatively strong katabatic flows (maximum winds of typically $8-10 \mathrm{~m} \mathrm{~s}^{-1}$ ) have a jet maximum between 20 and $60 \mathrm{~m}$ above the surface and are relatively deep (up to $200 \mathrm{~m}$ ); while moderate katabatic flows (4$\left.8 \mathrm{~m} \mathrm{~s}^{-1}\right)$ typically have a jet maximum between 3 and $30 \mathrm{~m}$ and are shallower $(\sim 100 \mathrm{~m})$, although they can also be more diffuse in structure with a wind speed maximum at higher altitude. In all katabatic flows there is backing of wind direction with height, consistent with decreasing friction away from the surface. During summertime katabatic flows there is a clear diurnal signature at all heights, although this is less pronounced in the surface layer where there seems to be a persistent $2-4 \mathrm{~m} \mathrm{~s}^{-1}$ katabatic flow during all case-studies. Where the diurnal forcing results in an abrupt katabatic flow deceleration, i.e. what may be a katabatic 'jump', there is a concurrent vertical acceleration. Wind profiles from a recent numerical weather prediction study of idealized katabatic flows at this site compare favourably with selected mean profiles; the only significant difference is that the model's wind speed is too low over the lowest $\sim 10 \mathrm{~m}$.

KEYWORDS: Doppler sodar Hydraulic jump Katabatic winds Low-level jet

\section{INTRODUCTION}

Katabatic flows are downslope buoyancy-driven flows. The domed topography and high-latitude locations of Antarctica and Greenland lead to a radiative cooling to space during the polar winter, and means that katabatic flows are ubiquitous over these regions. The basic physical process is as follows. A long-wave radiative loss to space leads to cooling of the snow surface and a compensating downward sensible-heat flux, which cools the atmospheric surface layer and forms a temperature inversion. In the presence of a slope, this induces a horizontal temperature (i.e. buoyancy) gradient, equivalent to a downslope horizontal pressure-gradient force, i.e. a katabatic force. The widespread nature of katabatic flows over Antarctica means that they contribute to the general atmospheric circulation of the southern hemisphere (e.g. Parish and Bromwich 1991, 1998). In addition, on reaching the coast katabatic flows interact with sea ice, polynyas, or the coastal ocean, thus playing a part in water mass conversions and the thermohaline circulation. In short, they are key components of the high-latitude climate system.

Observations of widespread katabatic flows, such as those over Antarctica and Greenland, have always been compromised by the obvious technical and logistical challenges of observing in extremely cold and remote environments. The earliest studies of Antarctic surface winds relied on patterns left in the snow (e.g. sastrugi) to infer climatological surface winds (e.g. Mather and Miller 1967) or were limited to manned observing stations (Lettau and Schwerdtfeger 1967). Subsequently automatic weather

* Corresponding author, present affiliation: School of Environmental Sciences, University of East Anglia, Norwich, Norfolk NR4 7TJ, UK. e-mail: i.renfrew@uea.ac.uk

(c) Royal Meteorological Society, 2006. 
stations (AWS) provided the means to obtain a high temporal-resolution year-round picture of the surface winds and, although numerous technical problems have been endured, these remain a mainstay of katabatic-flow studies (e.g. Parish 1988; Stearns and Wendler 1988; Bromwich 1989; Pettré and André 1991; King 1993; Renfrew and Anderson 2002) their main limitation being that the height of the AWS mast (typically $3 \mathrm{~m}$ ) usually allows only one level of near-surface wind measurement.

Observations of the vertical structure of katabatic flows are rare. The manned research stations in both Greenland and Antarctica are mainly around the coast on islands, ice shelves or nunataks, and naturally these tend to avoid areas prone to katabatic winds. The few manned stations in the interior (e.g. Amundsen-Scott at the South Pole, Dome C, Vostok) tend to be on very slight slopes, or plateaux, where any katabatic forcing is very weak. This means that observational studies of katabatic flow structure thus far have been remotely based field experiments and so have been restricted to the summer months.

Over Greenland and Antarctica, intensive field experiments have been carried out using aircraft, tethersondes, radiosondes and sodar, usually augmented by surface observations from AWS. For example, at the western margins of Greenland, van den Broeke et al. (1994) used tethersonde observations and Meesters et al. (1997) used mast and sodar observations to describe the average structure of katabatic winds during summer conditions. Over western and eastern Greenland, Heinemann $(1999,2002)$ used a research aircraft to obtain numerous soundings of early summer katabatic flows and, due to the comprehensive sampling carried out, was able to quantify the momentum budget of the flow and its turbulent structure. Over Adélie Land, in Antarctica, as part of the IAGO (Interaction Atmosphere-Glace-Ocean) campaign, Sorbjan et al. (1986) and Pettré and André (1991) used tethersonde and radiosonde observations to describe the summertime atmospheric boundary layer. Near Siple Coast, Bromwich and Liu (1996) used sodar, a radio acoustic sounding system and radiosonde soundings to describe summertime katabatic flows; while over Dronning Maud Land, Bintanja $(2000 \mathrm{a}, \mathrm{b})$ combined simultaneous tethersonde and radiosonde soundings to calculate an approximate momentum budget of summertime katabatic flow. Outside of these few intensive but short-lived summertime field campaigns there are relatively few observations of the vertical structure of katabatic flow in Antarctica (e.g. Ohata et al. 1985) or Greenland.

This paper presents extensive year-round observations of the vertical structure of katabatic flow over Coats Land, Antarctica from 2002 and 2003. The wind profiles are derived from an autonomous Doppler sodar sounding system installed on a moderate slope some $50 \mathrm{~km}$ south of Halley Research Station. The moderate uniform slopes of Coats Land are typical of much of coastal Antarctica, suggesting these observations are representative of katabatic winds on similar slopes around the continent. The wind profiling system could not be run continuously due to power supply limitations. Instead, 'case-study' periods of a few hours to days were sampled, chosen on the basis of real-time meteorological information provided by an in situ AWS. The Doppler sodar system sampled continuously during these periods, thus providing a wealth of data for a selection of cases, allowing a comprehensive picture of the temporal variability of the katabatic flows and amassing a large number of wind profiles without the labour of a tethersonde or radiosonde system. A total of over 2600 vertical wind profiles were observed over the 2-year period. Significant observational periods have been subjectively classified as: synoptically driven, katabatically influenced (28 days and 1626 profiles); or primarily katabatically driven flows (a subset of 16 days and 805 profiles); or other flow types. 


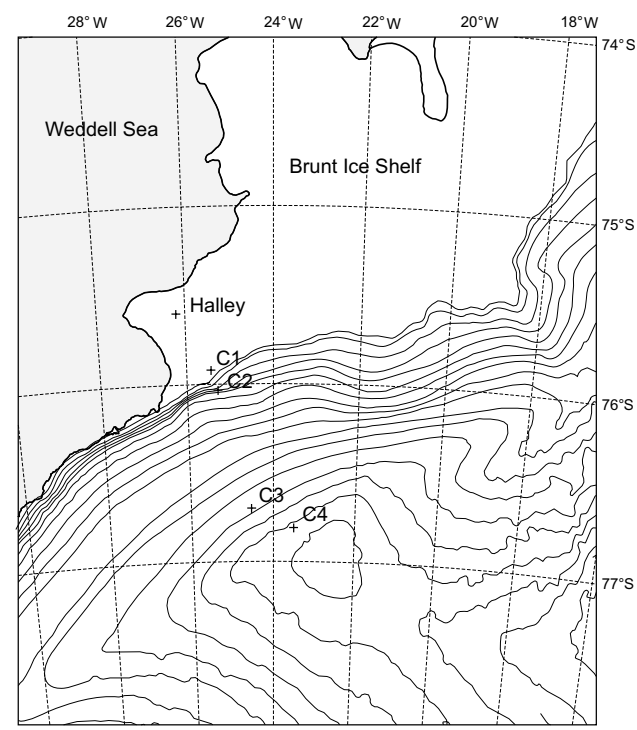

Figure 1. Topographic map of Coats Land, Antarctica, based on the Antarctic Digital Database version 3 (BAS 1993). The contour interval is $100 \mathrm{~m}$. The location of Halley Research Station is shown, and the four automatic weather station sites are marked C1 to C4. The autonomous Doppler sodar was deployed at C2 during 2002 and 2003.

In the next section further details on the Coats Land experiment, a summary of Coats Land's surface climatology and a brief description of the autonomous Doppler sodar system are presented. In section 3, two katabatic flow case-studies (one from summer and one from winter) are described and used to illustrate the profile data. In section 4 , a composite analysis of the vertical structure of primarily katabatic flow is carried out, while section 5 presents conclusions.

\section{THE COATS LAND EXPERIMENT}

Coats Land lies in the Weddell Sea sector of Antarctica. Figure 1 shows a topographic map of the area, based on the Antarctic Digital Database version 3 (BAS 1993). The location of Halley and four AWS sites $(\mathrm{C} 1$ to $\mathrm{C} 4)$ are marked. Table 1 notes some geographical details of the sites. The slopes of Coats Land consist of a snow-covered ice sheet which is uniform across and modest in gradient (around 5\% at most), relative to the Antarctic continent in general. The coastline is typical of much of the moderate slopes of the continent. The proximity of Coats Land to the British Antarctic Survey's Halley research station, on the Brunt Ice Shelf, suggests it as an ideal location to study 'ordinary' Antarctic katabatic flows, i.e. those that develop on relatively modest, uniform slopes (as opposed to the 'extraordinary' katabatic flows found over very steep or convergent topography, e.g. Bromwich (1989) and Wendler et al. (1993)). The Coats Land experiment ran from 1996 to the end of 2004, with AWS located at various sites over this period (for more details see Renfrew and Anderson 2002; Anderson et al. 2005).

A description of the surface climatology of Coats Land based primarily on AWS and Halley surface observations, but augmented with satellite products and upper-air radiosonde soundings, is documented in Renfrew and Anderson (2002). They describe two dynamical regimes in the region: over the ice shelf near-surface winds were usually 
TABLE 1. Geographical data for Halley AND the CoAts LAND AUtomatic weather STATIONS, C1 TO C4

\begin{tabular}{lccccccc}
\hline Station & $\begin{array}{c}\text { Latitude } \\
\left({ }^{\circ} \mathrm{S}\right)\end{array}$ & $\begin{array}{c}\text { Longitude } \\
\left({ }^{\circ} \mathrm{W}\right)\end{array}$ & $\begin{array}{c}\text { Height } \\
(\mathrm{m})\end{array}$ & $\begin{array}{c}\text { Slope } \\
(\%)\end{array}$ & Fall line & $\begin{array}{c}\text { Distance from } \\
\text { Halley } \\
(\mathrm{km})\end{array}$ & $\begin{array}{c}\text { Distance to } \\
\text { downslope station } \\
(\mathrm{km})\end{array}$ \\
\hline Halley & 75.60 & 26.20 & 37 & 0.07 & 155 & 0 & - \\
C1 & 75.88 & 25.49 & 43 & 0.7 & 160 & 37 & 37 \\
C2 & 75.96 & 25.41 & 400 & 5.5 & 165 & 46 & 10 \\
C3 & 76.70 & 24.53 & 1400 & 1.0 & 150 & 132 & 86 \\
C4 & 76.81 & 23.50 & 1650 & 0.8 & 145 & 155 & 32 \\
\hline
\end{tabular}

After Renfrew and Anderson (2002).

(a)

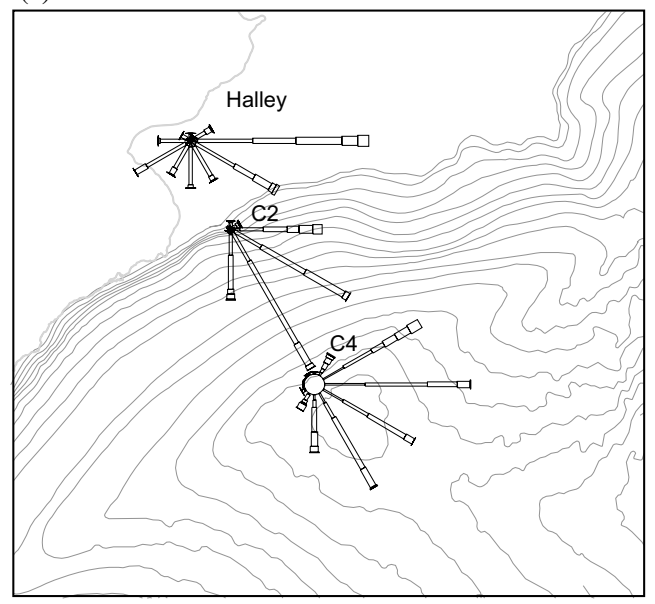

(b)

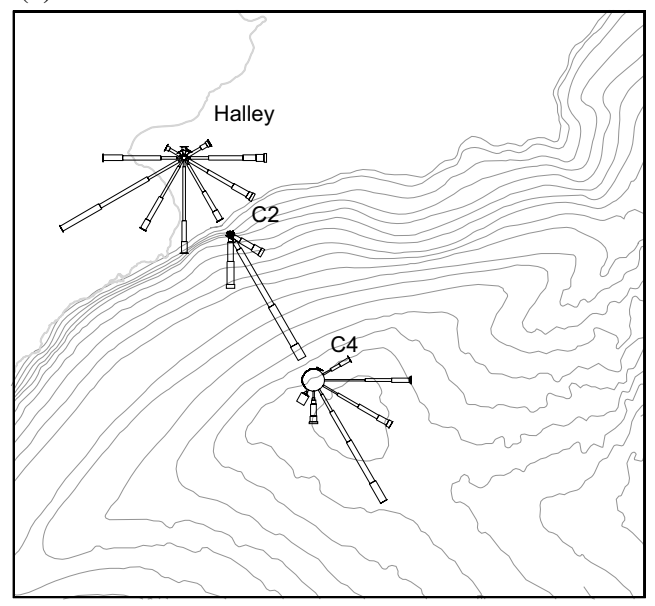

Figure 2. Wind roses for Halley and automatic weather stations C2 and C4: (a) for all matching wintertime observations during the period 1996-2000, and (b) during katabatic conditions at C2, as determined by conditional sampling. The wind directions are divided into $30^{\circ}$ bins, and the wind speeds into $5 \mathrm{~m} \mathrm{~s}^{-1}$ bins from 0.1 to $30 \mathrm{~m} \mathrm{~s}^{-1}$. The size of the centre circle is proportional to the number of calm observations. The wind roses are plotted over the topography as shown in Fig. 1. (From Renfrew and Anderson 2002.)

from the east, occasionally from the west; whereas over the Coats Land slopes winds were from the east-to-south quadrant (Fig. 2(a)). Excluding the summer months, the surface layer over the ice shelf was about $10 \mathrm{~K}$ colder, in terms of potential temperature, than over the continent and was more stable than on the steepest part of the slope.

Motivated by case-studies and theoretical arguments, Renfrew and Anderson (2002) used a conditional sampling method to select a subset of the AWS data the members of which are, in some sense, katabatic*. Examining these data (Fig. 2(b)), the authors showed that these archetypal katabatic winds flow from around $10^{\circ}$ to the east of the fall line and with near-surface wind speeds of $7.5 \mathrm{~m} \mathrm{~s}^{-1}$ at the $\mathrm{C} 2$ site (the steepest part of the slope), $5.1 \mathrm{~m} \mathrm{~s}^{-1}$ at the $\mathrm{C} 3$ site, and $3.8 \mathrm{~m} \mathrm{~s}^{-1}$ at the $\mathrm{C} 4$ site. They found no coherent surface katabatic-flow signature over the Brunt Ice Shelf-an aspect of the local climate also discussed by King (1993). King et al. (1998) used satellite remote sensing to infer a change in the temperature structure from the Brunt Ice Shelf to the slopes of Coats Land. This was investigated further by Renfrew and Anderson (2002) who found that during katabatic conditions potential temperatures over the ice shelf were also, on average,

* The selection procedure chooses wintertime data where the perturbation pressure gradient between the AWS and Halley is small and the surface-layer stability is large-see Renfrew and Anderson (2002) for details. 
some $10 \mathrm{~K}$ lower than over the continent. They therefore hypothesized that a damming, due to this pool of cold air in the ice shelf boundary layer, was causing the katabatic winds flowing from the continental slopes to ride over the boundary layer and/or be dissipated in some way as the flow decelerates (e.g. Ball 1960; Gallée and Schayes 1992; Gallée and Pettré 1998; Heinemann 1999). This hypothesis was confirmed by a momentum budget analysis in the numerical modelling study of Renfrew (2004).

According to this surface climatology, the AWS site subject to the strongest katabatic flows was $\mathrm{C} 2$; while according to the idealized numerical modelling of Renfrew (2004), the area of strongest katabatic winds stretched from just below C3 to just below $\mathrm{C} 2$. For this reason the $\mathrm{C} 2$ site was chosen for the installation of the Doppler sodar wind profiling system; the aim was to observe the vertical structure and variability of katabatic flows within a relatively dense (at least for the Antarctic) regional observing network.

The autonomous Doppler sodar wind profiling system was deployed at the C2 site for a subset of the full study period: namely 2002 and 2003. Prior to deployment the system was developed and tested in the UK and in Antarctica at Halley. The wind profiling system was based on a multi-frequency phased-array sodar, able to transmit acoustic pulses in several directions and hence use Doppler technology to calculate a three-dimensional wind profile from the acoustic returns. The sodar was powered by a parallel series of modules, each containing batteries, photovoltaic solar panels and vertical-axis wind generators, along with charging control and isolation circuitry. Unfortunately the wind generators failed during 2002, consequently there was only the stored battery power during the unlit winter of 2003. The main sodar processing unit was local to the antenna at the $\mathrm{C} 2$ site, but a radio telemetering system was devised to allow remote operation and data download from Halley (50 km to the north) via controlling software on a PC. An AWS was integrated into the system to provide realtime meteorological observations from the experimental site. Figure 3 shows the $\mathrm{C} 2$ site after the initial deployment of the autonomous Doppler sodar in January 2002. A detailed description of the system design and an evaluation of its performance can be found in Anderson et al. (2005).

A number of range-gate, pulse-frequency and pulse-duration settings were tried during the test phases of the experiment and, as with all sodar equipment, there was a trade-off between higher signal-to-noise ratios (achieved through longer pulse durations) and higher vertical resolution (achieved through closer range gates). In the end two settings were used during deployment in Coats Land: setting 502 (high vertical resolution) with range gates of $10 \mathrm{~m}$ from 20 to $60 \mathrm{~m}, 20 \mathrm{~m}$ from 60 to $120 \mathrm{~m}, 30 \mathrm{~m}$ from 120 to $210 \mathrm{~m}, 40 \mathrm{~m}$ from 210 to $330 \mathrm{~m}, 50 \mathrm{~m}$ from 330 to $430 \mathrm{~m}$, and $70 \mathrm{~m}$ from 430 to $500 \mathrm{~m}$; and setting 506 (standard vertical resolution) with range gates of $20 \mathrm{~m}$ from 20 to $100 \mathrm{~m}, 30 \mathrm{~m}$ from 100 to $220 \mathrm{~m}, 40 \mathrm{~m}$ from 220 to $340 \mathrm{~m}, 50 \mathrm{~m}$ from 340 to $440 \mathrm{~m}$, and $60 \mathrm{~m}$ from 440 to $500 \mathrm{~m}$. The frequencies and pulse durations prescribed can be found in Anderson et al. (2005). An analysis of data quality as a function of height showed a monotonic decrease with each successive range gate; in other words, using the 502 setting gave better vertical resolution at the expense of range, while using the 506 setting compromised resolution for a longer range (Anderson et al. 2005). According to the design specification of the Doppler sodar, wind accuracies are in the ranges: $0.1-$ $0.3 \mathrm{~m} \mathrm{~s}^{-1}$ for horizontal wind speed, 2-3 $3^{\circ}$ for wind direction, and $0.03-0.1 \mathrm{~m} \mathrm{~s}^{-1}$ for vertical wind speed, depending upon the prescribed settings. Qualitative comparisons against tethersonde wind profiles are discussed in Anderson et al. (2005).

The autonomous Doppler sodar system was designed to allow sounding for casestudy periods (or intensive observing periods) of a few hours to a few days. Continuous operation of the system was not possible due to power supply constraints. Therefore a 


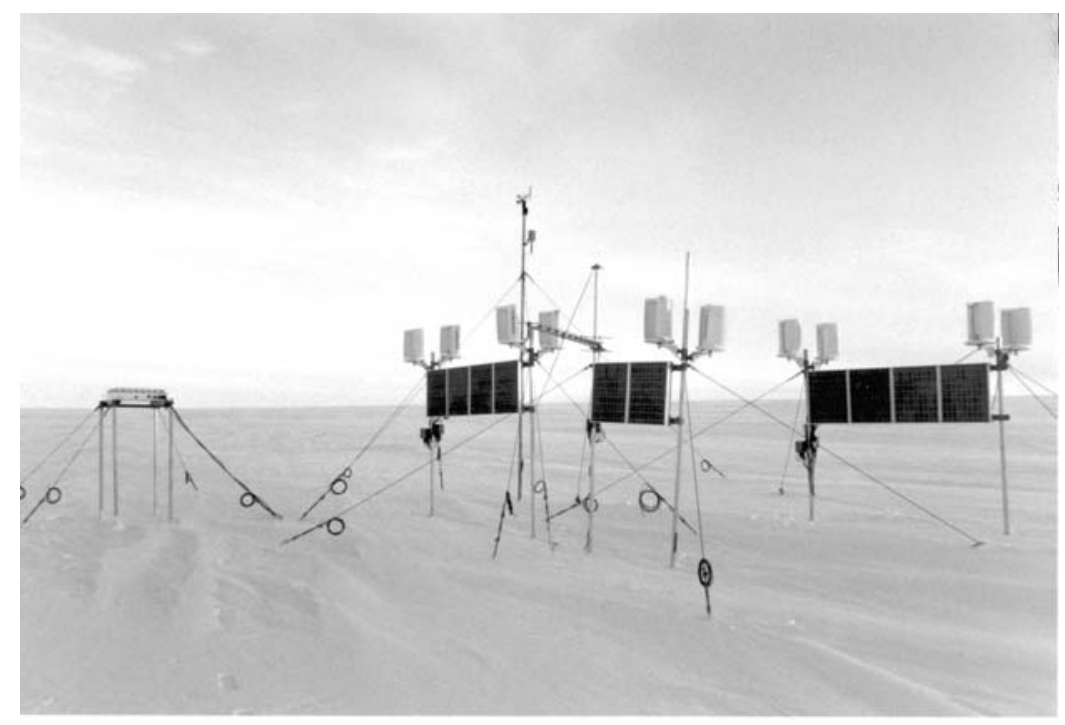

Figure 3. Photograph of the autonomous Doppler sodar wind profiling system situated at the C2 automatic weather station (AWS) site south of Halley in January 2002, looking towards the south-east. To the left is the sodar antenna, raised around $2 \mathrm{~m}$ above the snow surface; to the right, arranged in three rows, are the ten solar panels and ten wind generators that are part of the power system. Pointing towards the camera is the radio antenna. Behind the solar panels is the mast of the integrated AWS, with the propeller-vane anemometer on top. Out of shot are two other independent AWSs (from Anderson et al. 2005).

sounding strategy was developed to try and capture as many periods of meteorological interest as possible. To determine whether to start a sounding episode, the Halley sodar operators addressed two questions: (i) is there adequate power, and (ii) are the meteorological conditions interesting?

The power available to the system was monitored via the battery input voltage which, along with other power measurements, was transmitted with the AWS observations every hour from the remote site to Halley. Meteorological conditions of interest were, essentially:

- Periods of primarily katabatic flow;

- Transitions into or out of katabatic flow; and

- Periods of synoptically influenced katabatic flow.

Table 2 summarizes the specific meteorological criteria for each of the above three scenarios, as devised before the experiment. These criteria are based on the climatological and case-study analyses of Renfrew and Anderson (2002).

The priority before the experiment was to obtain several case-study periods of each scenario, with a particular priority being wintertime katabatic flow due to the scarcity of such data from anywhere in Antarctica. Indeed, for this reason no soundings were carried out during March and April 2003, instead the battery power was saved until the winter months of May to September. In addition to the above criteria, a preliminary analysis of the data was possible because the sounding data were transmitted back to Halley, and that analysis was then able to inform any modifications to the sounding strategy. Obviously a regular correspondence between the sodar operators at Halley and the research scientists working in the UK was maintained throughout the 2-year experiment. 
TABLE 2. METEOROLOGICAL SOUNDING CRITERIA BASED ON REAL-TIME SURFACE OBSERVATIONS FROM THE C2 AUtOMATIC WEATHER STATION SITE AND HALLEY RESEARCH STATION

\begin{tabular}{|c|c|c|c|}
\hline Scenario & Description & $\mathrm{C} 2$ criteria & Halley criteria \\
\hline A & Wintertime katabatic flow & $\begin{array}{l}5<\text { wind speed }<10 \mathrm{~m} \mathrm{~s}^{-1} \\
120<\text { wind direction }<180^{\circ} \\
\text { 'clear skies' observed or } \\
\text { clear satellite image }\end{array}$ & $\begin{array}{l}\text { Cloud }<3 \text { octas } \\
\text { sun below horizon }\end{array}$ \\
\hline B & $\begin{array}{l}\text { Summertime katabatic } \\
\text { flow }\end{array}$ & As A & $\begin{array}{l}\text { As A, except sun above } \\
\text { horizon }\end{array}$ \\
\hline $\mathrm{C}$ & $\begin{array}{l}\text { Calm to katabatic } \\
\text { flow transition }\end{array}$ & $\begin{array}{l}\text { Initially: } 0<\text { wind speed }<5 \mathrm{~m} \mathrm{~s}^{-1} \\
\text { becoming: as A }\end{array}$ & $\begin{array}{l}\text { Cloud }<3 \text { octas } \\
0<\text { wind speed }<5 \mathrm{~m} \mathrm{~s}^{-1}\end{array}$ \\
\hline $\mathrm{D}$ & $\begin{array}{l}\text { Synoptic-scale low to } \\
\text { katabatic flow transition }\end{array}$ & $\begin{array}{l}\text { Initially: } 10 \mathrm{~m} \mathrm{~s}^{-1}<\text { wind speed } \\
60<\text { wind direction }<150^{\circ} \\
\text { becoming: as A }\end{array}$ & $\begin{array}{l}10 \mathrm{~m} \mathrm{~s}^{-1}<\text { wind speed } \\
60<\text { wind direction }<120^{\circ} \\
\text { becoming: as A }\end{array}$ \\
\hline
\end{tabular}

Halley is a synoptic and upper-air meteorological observing station, so standard meteorological variables are recorded continuously and cloud observations every 3 hours. The $\mathrm{C} 2$ site, around $50 \mathrm{~km}$ to the south and on the continental slope, is visible during clear-sky conditions and daylight hours, so 'clear skies' there can be seen from Halley. In addition, a satellite receiving system could be checked for the regional cloud cover.

Table 3 provides an overview of the katabatic flow observations obtained from the Doppler sodar system during its deployment in Coats Land. The table does not include very short periods of data (less than a few hours), nor periods where the range was very poor, nor periods of system testing. In total there are 28 days of sounding during what could be described as katabatically influenced flow; these comprise 1626 vertical wind profiles (each a 15-minute average), with 655 of these using setting 502, and 971 using setting 506. Mean vertical ranges for each day were between 68 and $221 \mathrm{~m}$ (Table 3), with the 506 setting giving a slightly better range, as expected. The maximum wind speed for each profile was determined and then averaged over each period to give a simple measure of the strength of flow; these mean (maximum) wind speeds ranged from 2.6 to $8.5 \mathrm{~m} \mathrm{~s}^{-1}$. As noted by Anderson et al. (2005) the Doppler sodar does not work for wind speeds much higher than $\sim 12 \mathrm{~m} \mathrm{~s}^{-1}$, due to contamination by wind-induced noise around the antenna. Also included in Table 3 are free-atmosphere observations of stability, potential temperature, wind speed and wind direction calculated as 400 $1000 \mathrm{~m}$ averages of the 12 UTC* $^{*}$ radiosonde soundings at Halley on that day. Given that the Doppler sodar site is $400 \mathrm{~m}$ above sea level, these should be broadly representative of the free atmosphere there since katabatic flow periods will tend to have weak baroclinicity.

\section{TwO CASE-STUDIES OF KATABATIC FLOW}

Here two periods of predominately katabatic flow are illustrated and briefly discussed. Many more periods have been examined and are being studied further in conjunction with numerical modelling experiments, so further interesting facets of these case-studies will be reported in due course.

\section{(a) A case of summertime katabatic flow}

Figure 4 shows a time series of horizontal wind vectors against height from the Doppler sodar for 23 February 2002, a day of primarily katabatic flow. Wind vectors are plotted every 15 minutes at the central height of each sounding layer (in this case 30, 50, $70,90,115,145,175,205 \mathrm{~m}$, etc). Also plotted every hour (at $3 \mathrm{~m}$ ) are the AWS wind

* Note that times are given as UTC, whilst local time is about $1 \mathrm{~h} 40$ minutes behind. 
TABLE 3. AN OVERVIEW OF THE DOPPLER SODAR WIND PROFILING PERIODS WHERE SIGNIFICANT OBSERVATIONS OF KATABATIC FLOW OVER THE C2 SITE WERE OBTAINED

\begin{tabular}{|c|c|c|c|c|c|c|c|c|c|}
\hline \multirow[b]{3}{*}{ Date } & \multirow{3}{*}{$\begin{array}{l}\text { Times } \\
\text { (h) }\end{array}$} & \multirow{3}{*}{$\begin{array}{l}\text { Sodar } \\
\text { setting }\end{array}$} & & & \multirow{3}{*}{$\begin{array}{c}\text { Mean } \\
\text { maximum } \\
\text { wind speed } \\
\left(\mathrm{m} \mathrm{s}^{-1}\right)\end{array}$} & \multicolumn{4}{|c|}{ Free atmosphere observations at Halley } \\
\hline & & & \multicolumn{2}{|c|}{ Vertical range $(\mathrm{m})$} & & \multirow{2}{*}{$\begin{array}{l}\text { Stability } \\
\left(\mathrm{K} \mathrm{m}^{-1}\right)\end{array}$} & \multirow{2}{*}{$\begin{array}{l}\text { Potential } \\
\text { temperature } \\
(\mathrm{K})\end{array}$} & \multirow{2}{*}{$\begin{array}{l}\text { Wind } \\
\text { speed } \\
\left(\mathrm{m} \mathrm{s}^{-1}\right)\end{array}$} & \multirow{2}{*}{$\begin{array}{c}\text { Wind } \\
\text { direction }\end{array}$} \\
\hline & & & mean & median & & & & & \\
\hline \multicolumn{10}{|l|}{2002} \\
\hline 22 February $\mathrm{K}$ & $00-24$ & 506 & 120 & 100 & 6.53 & 0.006 & 272 & 3.0 & 107 \\
\hline 23 February $\mathrm{K}$ & $00-24$ & 506 & 125 & 100 & 5.20 & 0.004 & 272 & 4.5 & 223 \\
\hline 24 February $\mathrm{K}$ & $00-24$ & 506 & 191 & 190 & 3.90 & 0.002 & 272 & 6.6 & 224 \\
\hline 25 February & $00-24$ & 506 & 200 & 190 & 4.20 & 0.009 & 272 & 3.5 & 226 \\
\hline 26 February & $00-24$ & 506 & 140 & 100 & 4.33 & 0.006 & 272 & 4.9 & 13 \\
\hline 27 February & $00-24$ & 506 & 170 & 160 & 2.60 & 0.006 & 272 & 1.4 & 0 \\
\hline 24 March & $13-24$ & 502 & 146 & 80 & 6.03 & 0.012 & 262 & 4.1 & 270 \\
\hline 25 March & $00-24$ & 502 & 68 & 60 & 6.33 & 0.011 & 265 & 3.3 & 39 \\
\hline 18 April & $17-24$ & 502 & 88 & 80 & 6.59 & 0.010 & 272 & 4.6 & 84 \\
\hline 19 April & $00-24$ & 502 & 136 & 120 & 4.11 & 0.013 & 271 & 3.4 & 210 \\
\hline 4 September ${ }^{K}$ & $14-18$ & 506 & 183 & 160 & 4.32 & 0.022 & 261 & 3.2 & 146 \\
\hline 12 September & $11-24$ & 502 & 208 & 180 & 2.76 & 0.017 & 262 & 2.8 & 141 \\
\hline 18 September & $11-24$ & 502 & 165 & 150 & 6.00 & 0.010 & 265 & - & - \\
\hline 12 October $^{\mathrm{K}}$ & $09-24$ & 502 & 69 & 60 & 5.20 & 0.003 & 266 & 3.4 & 207 \\
\hline 13 October $\mathrm{K}$ & $00-09$ & 502 & 111 & 90 & 2.86 & - & - & - & - \\
\hline \multicolumn{10}{|l|}{2003} \\
\hline 18 May $^{K}$ & $11-17$ & 506 & 124 & 100 & 7.84 & 0.013 & 264 & 4.0 & 130 \\
\hline 24 June & $10-24$ & 506 & 198 & 220 & 7.69 & 0.019 & 262 & 5.4 & 111 \\
\hline 25 June & 00-09 & 506 & 171 & 190 & 6.37 & 0.017 & 268 & 3.0 & 136 \\
\hline 14 August $\mathrm{K}$ & $10-16$ & 506 & 125 & 100 & 4.97 & -0.001 & 256 & 5.0 & 239 \\
\hline 28 August $\mathrm{K}$ & $12-21$ & 506 & 123 & 100 & 8.12 & 0.016 & 264 & 5.2 & 112 \\
\hline 8 September $\mathrm{K}$ & $10-15$ & 502 & 69 & 55 & 8.54 & 0.001 & 260 & 9.6 & 38 \\
\hline 18 September $^{K}$ & $09-24$ & 502 & 188 & 180 & 3.94 & 0.014 & 265 & 4.0 & 187 \\
\hline 19 September $^{K}$ & $00-07$ & 502 & 148 & 120 & 6.91 & 0.018 & 268 & 6.1 & 172 \\
\hline 9 October $\mathrm{K}$ & $20-24$ & 506 & 221 & 190 & 5.30 & 0.014 & 260 & 4.1 & 159 \\
\hline 10 October $^{\mathrm{K}}$ & $00-08$ & 506 & 206 & 190 & 3.71 & 0.015 & 259 & 3.1 & 70 \\
\hline 14 November $^{\mathrm{K}}$ & $00-24$ & $502 / 506$ & 146 & 130 & 5.05 & 0.009 & 269 & 1.2 & 170 \\
\hline 15 November & $00-21$ & $506 / 502$ & 106 & 80 & 6.37 & 0.004 & 273 & 1.4 & 300 \\
\hline 1 December $\mathrm{K}$ & $00-12$ & 506 & 148 & 100 & 4.79 & 0.006 & 274 & 1.3 & 87 \\
\hline
\end{tabular}

Times in the second column are start and end times to the nearest hour. Values of stability, potential temperature, wind speed and wind direction of the free atmosphere are averages between 400 and $1000 \mathrm{~m}$, derived from the 12 UTC radiosonde soundings at Halley. Although Halley is some $50 \mathrm{~km}$ distant from the $\mathrm{C} 2$ site, it should be representative of the background free atmosphere over $\mathrm{C} 2$ during these conditionally sampled periods. The layer between $400-1000 \mathrm{~m}$ was chosen as the C2 site is approximately $400 \mathrm{~m}$ in altitude. Days where the flow is determined to be primarily katabatically forced are marked with superscript $\mathrm{K}$.

vectors for $\mathrm{C} 2$. Note these are 10-second averages, compared to the 15-minute averages of the sodar. For cases of relatively steady flow this discrepancy is unimportant, but for rapidly changing flow it could lead to a mismatch when trying to splice the two observational datasets together to create a wind profile. Certainly the different sampling times must be borne in mind when analysing these data.

Figure 4 shows a well-defined diurnal katabatic flow signature, that is, a lowlevel jet with a monotonic decrease in wind speed with height above it. There is an anticlockwise backing of the wind with height, most sharply between 3 and $30 \mathrm{~m}$ where the change in wind direction is typically $30^{\circ}$ to $45^{\circ}$. This is indicative of decreasing frictional forcing with height through the boundary layer. The winds at $3 \mathrm{~m}$ are close to downslope, i.e. from close to $165^{\circ}$ (Table 1 ), while aloft they are typically south-easterly. There is a clear diurnal signal in the shape of the profiles and the flow strength, with a deeper jet and stronger winds at night and a shallower jet and weaker winds during 


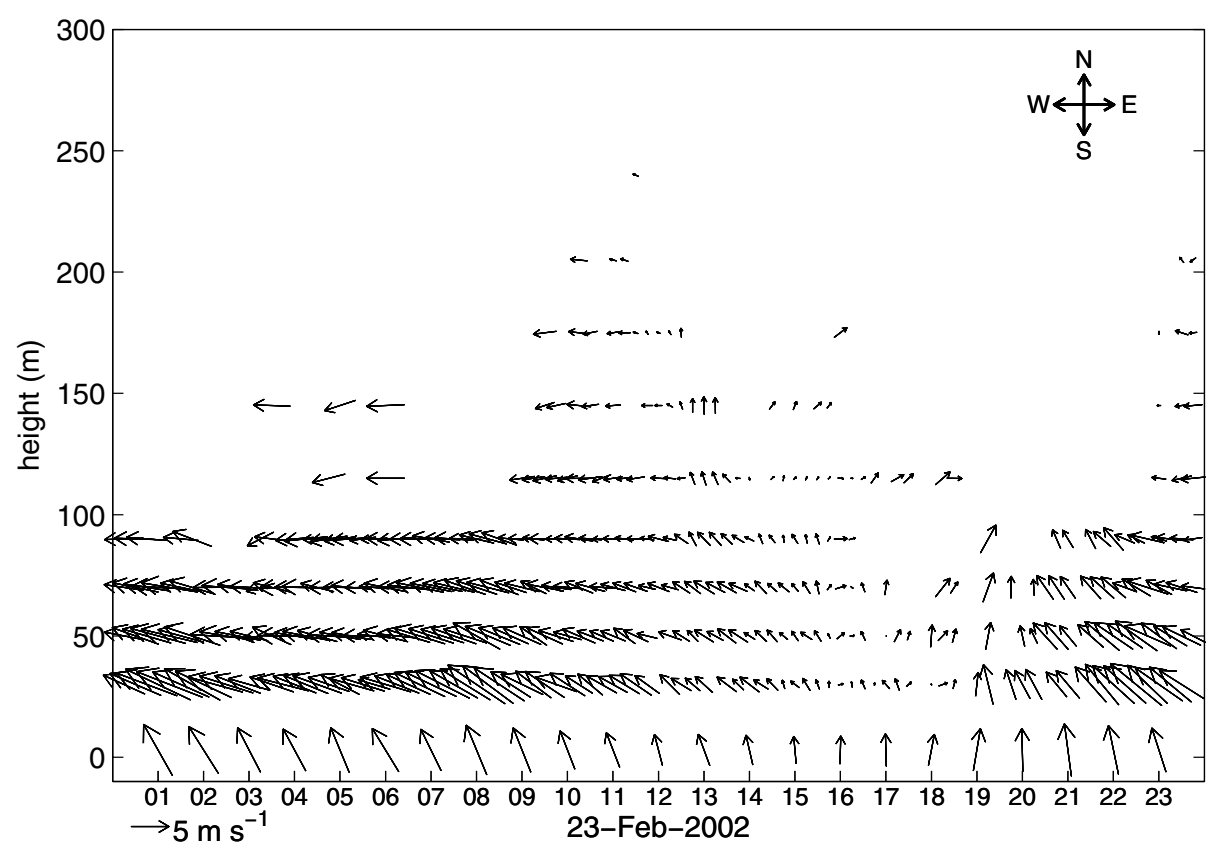

Figure 4. Time series of horizontal wind profiles for 23 February 2002 from the Doppler sodar south of Halley. Wind vectors are plotted every 15 minutes, each representing a 15-minute average. Also plotted every hour are wind vectors from an automatic weather station at C2 (see Fig. 1). Tick marks are every hour as labelled, and a scale arrow is shown in the lower left-hand corner.

the day. At this time of year and this latitude $\left(76^{\circ} \mathrm{S}\right)$ there is a clear diurnal signal in incoming solar radiation which, for clear-sky conditions, is manifest as a diurnal signal in surface air temperature (e.g. see Fig. 5). This leads to a diurnal change in the local katabatic forcing (becoming greater at night) and so a diurnal change in the observed flow. In this case, the daytime decrease in wind speed occurs at all levels, but is more pronounced between 30 and $100 \mathrm{~m}$ where winds drop to $\sim 1 \mathrm{~m} \mathrm{~s}^{-1}$, than at $3 \mathrm{~m}$ where there is still a $3-4 \mathrm{~m} \mathrm{~s}^{-1}$ flow. This suggests that a weak, shallow, katabatic flow persists through the day, gathering speed and depth during the night.

This situation is typical of the summertime katabatic flow cases observed. Indeed, plots of maximum wind speed (of each profile) versus time for all the summertime katabatic cases (November-February) illustrate a clear diurnal cycle, with maximum winds dropping to 2-4 $\mathrm{m} \mathrm{s}^{-1}$ between 13 and 16 UTC (not shown). There was a less pronounced cycle for spring/autumn cases (March to April and October) and no discernible diurnal cycle for wintertime cases (May to September). A diurnal signature in katabatic flow has been observed before in AWS observations and numerical simulations (e.g. Gallée et al. 1996; Gallée and Pettré 1998) and in tethersonde profiles (e.g. Sorjban et al. 1986; van den Broeke et al. 1994). There is also some variability in the katabatic flow strength between about 01 and 10 UTC, appearing as an oscillation in the flow with a period of $\sim 3 \mathrm{~h}$. This may be due to some mesoscale variability of the background atmospheric flow encroaching into the katabatic layer, or perhaps due to the advection of differing strengths of katabatic flow over this site.

Figure 5 shows a time series of horizontal wind vectors, potential temperature $(\theta)$, perturbation pressure $\left(p^{\prime}\right)$, total cloud amount and relative humidity with respect to ice $\left(R H_{\text {ice }}\right)$ from Halley and the three operational AWS sites $\mathrm{C} 2, \mathrm{C} 3$ and $\mathrm{C} 4$ (see Fig. 1 for 

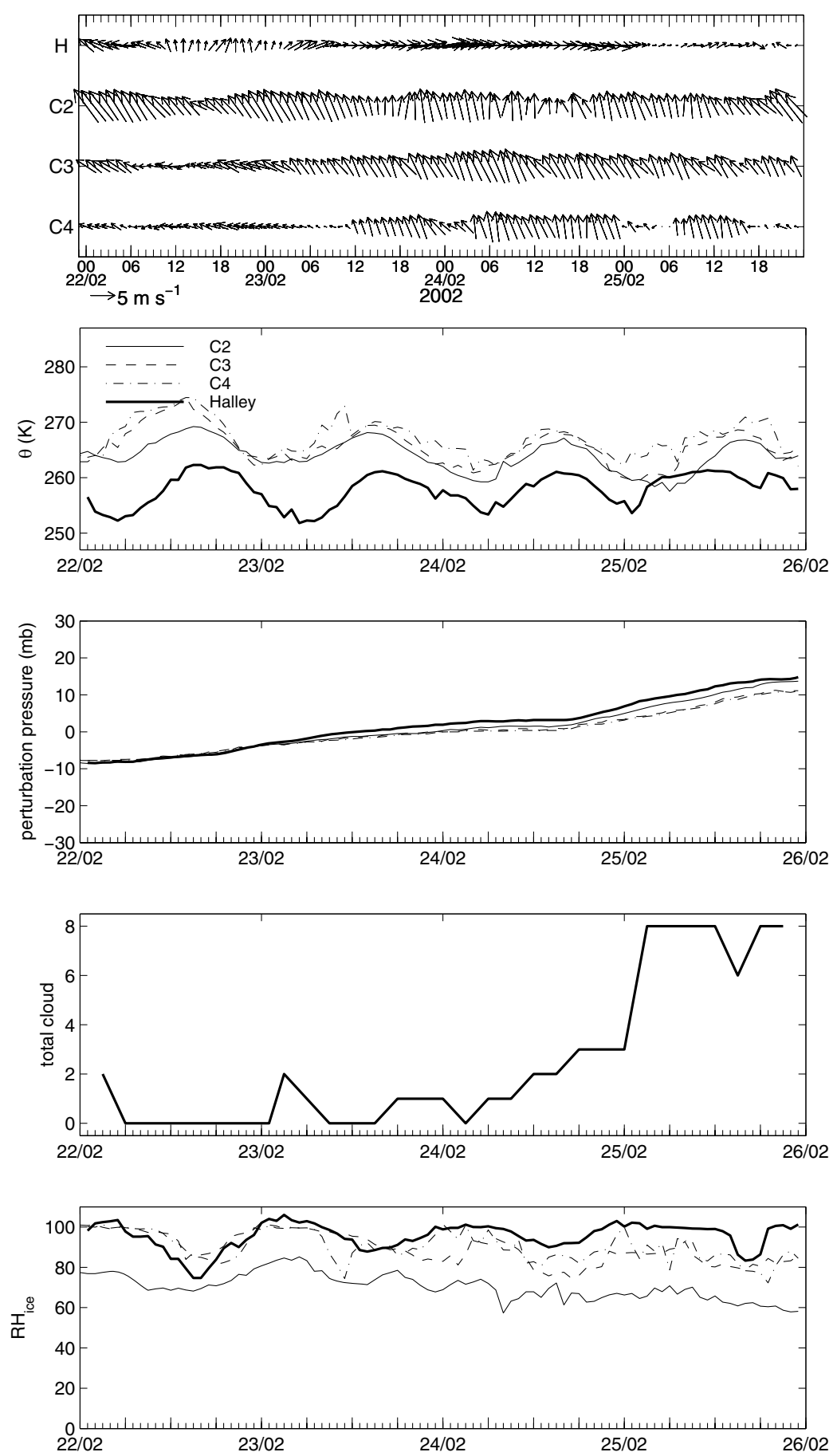

Figure 5. Time series of winds, potential temperature $(\theta)$, perturbation pressure, total cloud amount and relative humidity with respect to ice $\left(R H_{\text {ice }}\right)$ for 22-25 February 2002 from Halley and automatic weather station sites $\mathrm{C} 2, \mathrm{C} 3$ and $\mathrm{C} 4$ as indicated. Hourly observations are shown, with tick marks every hour and long ticks every 6 hours. A scale arrow is shown in the lower left-hand corner of the wind vector panel. 
locations) for 22 to 25 February 2002. There is persistent downslope flow at $\mathrm{C} 2$ over this period, with a clear diurnal signal. At the higher $\mathrm{C} 3$ and $\mathrm{C} 4$ sites during the 22nd the winds are more cross-slope and weaker-coincident with higher potential temperatures than at $\mathrm{C} 2$ and compared to the rest of the period (when $\theta$ is approximately the same at all the AWS sites). These temperature differences are probably due to minor changes in the background flow over the period. The situation of calm conditions at the $\mathrm{C} 4$ site during downslope flow at the lower sites was often observed; for example it is implicit in the wind roses of Fig. 2(b). Renfrew and Anderson (2002) show that during katabatic conditions at $\mathrm{C} 2$ one of three conditions is possible at $\mathrm{C} 4$ : calm conditions (as seen at times on 25 February in Fig. 5), low wind speeds from the east (as seen on 22 February) or moderate winds from the east-south-east to south (as seen from 12 UTC 23 February onwards).

At Halley the winds veer from easterly to westerly over 22 to 24 February, under the influence of a weak ridge of high pressure over the southern Weddell Sea. Note that mean-sea-level pressure (m.s.l.p.) analyses from ECMWF (the European Centre for Medium-range Weather Forecasts) were examined for all case-studies. In this case, over Coats Land the synoptic-scale 'background' flow is generally weak and not greatly affecting the observed mesoscale flows that are of interest (m.s.l.p. not shown). This is also apparent in the $p^{\prime}$ time series, which shows relatively little spreading and low curvature -indicating a relatively 'slack' background pressure field during this period. Note that $p^{\prime}$ is calculated as the deviation from the monthly mean station pressure, so a spreading of the station $p^{\prime}$ implies a pressure gradient and local minima correspond to significant low-pressure systems (for further details see Renfrew and Anderson 2002). Figure 5 illustrates that there is little observed cloud and the katabatic flow is relatively dry- $R H_{\text {ice }}$ is not saturated at the AWS sites, as is usually the case for a quiescent atmosphere over an ice surface (King and Anderson 1999).

The weak synoptic-scale pressure field, clear skies, and phasing of the winds and $\theta$ at the Coats Land sites indicate that the flow here is being katabatically forced. The offset in the initiation of downslope flow over the three AWS sites implies that the downslope katabatic force acts inhomogenously down the slope (assuming the same background forcing). In a simple two-layer model of katabatic flow (e.g. see Ball 1956; Mahrt 1982) the katabatic (or buoyancy) forcing can be calculated as:

$$
F_{\mathrm{b}}=g\left(\Delta \theta / \theta_{0}\right) \alpha,
$$

where $g$ is the acceleration due to gravity, $\Delta \theta$ is the potential-temperature deficit, $\theta_{0}$ is a reference potential temperature and $\alpha$ is the positive slope angle. $F_{\mathrm{b}}$ acts in the downslope direction. Referring to Table 3, the free-atmosphere $\theta$ at 12 UTC on $22-25$ February is $272 \mathrm{~K}$, thus for 22 February (subtracting the free-atmosphere $\theta$ from the AWS $\theta$ ) $\Delta \theta \approx 4 \mathrm{~K}$ at $\mathrm{C} 2$, but $\Delta \theta \approx 0 \mathrm{~K}$ higher up at $\mathrm{C} 3$ and $\mathrm{C} 4$-implying a katabatic forcing at $\mathrm{C} 2$, but none at $\mathrm{C} 3$ or $\mathrm{C} 4$. A day later, on 23 February, the $\mathrm{C} 3$ and $\mathrm{C} 4$ temperatures are lower-implying a katabatic forcing there, coincident with the observed downslope winds. In this case the differences in $F_{\mathrm{b}}$ at the three sites explain the different start times for downslope flow.

It is also worth noting that the downslope $F_{\mathrm{b}}$ at $\mathrm{C} 2$ is for $12 \mathrm{UTC}$. Hence for this case there is a local katabatic forcing during the day, which probably explains the persistent weak katabatic flow observed at the $3 \mathrm{~m}$ level. Inspection of the $\theta$ time series shows positive $\Delta \theta$ values at $\mathrm{C} 2$ throughout the period 22-25 February (Fig. 5), suggesting that this is the situation for this entire period. As noted earlier, at this time of year there is a clear diurnal signal in solar radiation and hence for surface air temperature (given clear-sky conditions). Surface energy-balance reasoning would suggest that the diurnal 


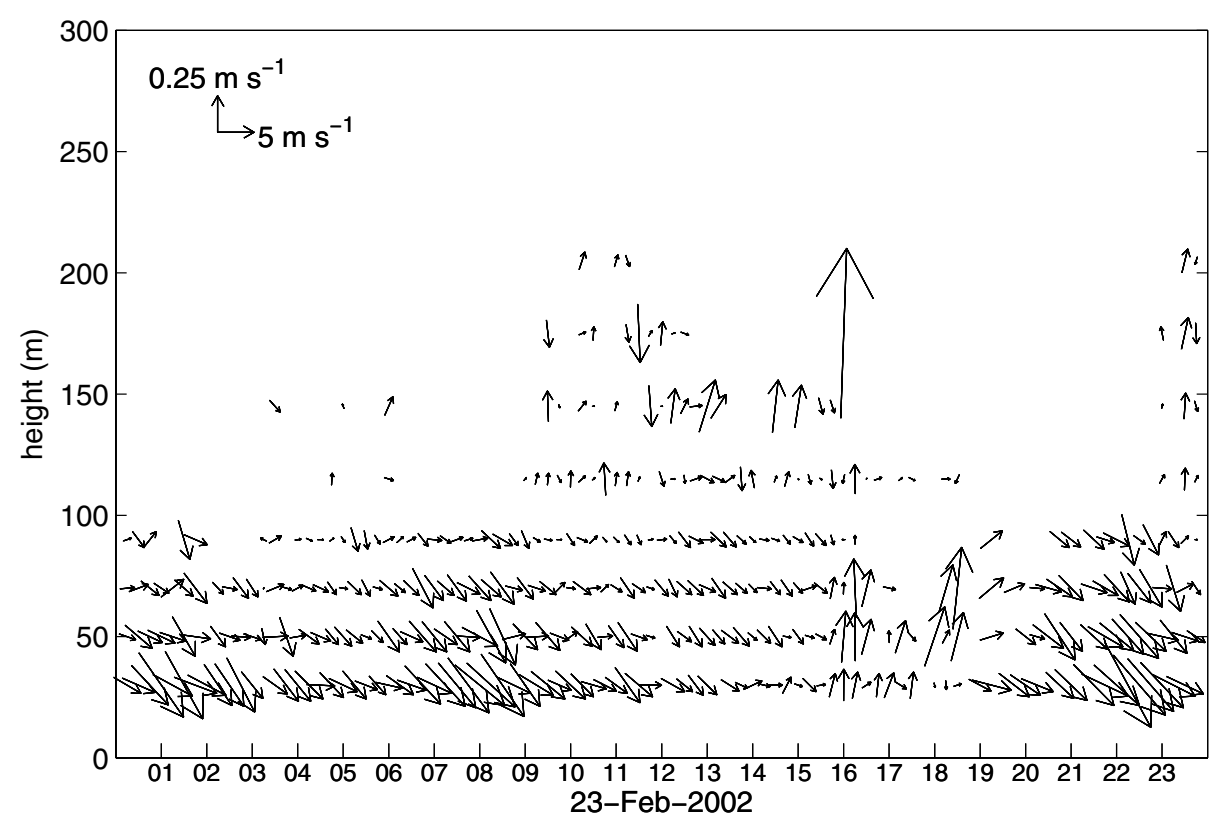

Figure 6. A downslope cross-section of horizontal and vertical winds as a function of time and height for 23 February 2002 from the Doppler sodar south of Halley. Wind profiles are plotted every 15 minutes, each representing a 15-minute average. A scaling arrow is shown in the top right-hand corner. The horizontal velocities are scaled by the slope angle (0.05), such that a slope-parallel flow will have an angle of $45^{\circ}$ from horizontal.

cycle near the surface is greater than that aloft, so one would expect a diurnal cycle in $F_{\mathrm{b}}$ and a consequent diurnal cycle in katabatic flow: weak flow during the day, stronger and deeper flow at night.

Figure 6 shows a time-height cross-section of wind vectors in the downslope vertical plane from the Doppler sodar for 23 February 2002, i.e. the same period as Fig. 4. The vector components are scaled by the slope ratio $(0.05)$ so that for flows parallel to the surface the vectors point at $45^{\circ}$ to the horizontal. The flow is in a downslope direction everywhere, but much stronger near the surface, indeed becoming almost stationary in the horizontal at $115 \mathrm{~m}$ and above. This suggests the katabatic flow has a depth of approximately $100 \mathrm{~m}$ in this case. There is generally descent into the katabatic layer as one would expect from large-scale continuity constraints, indeed the flow is often approximately parallel to the surface. The stronger horizontal winds are generally coincident with periods of stronger descent, such as around 01-03 UTC and $08-09$ UTC. Between 16 and 18 UTC $(\approx 14$ and 16 local time) the downslope flow ceases and there are dramatic upward velocities. Assuming the flow upslope of this location persists, as suggested by Fig. 5, then the horizontal flow cessation must lead to convergence and hence ascent. In this summertime case the cessation of the katabatic flow is linked to the diurnal cycle and a weakening of the potential-temperature deficit (the maximum near-surface temperature during clear-sky conditions is around 14-18 UTC-see Fig. 5). The abrupt cessation of katabatic flows has been observed before in surface pressure, temperature and horizontal wind data (e.g. Pettré and André 1991). Here it is clear that the cessation occurs throughout the boundary layer and there is a dramatic vertical velocity response that is coherent with height. The observed upward velocities are typically $0.5 \mathrm{~m} \mathrm{~s}^{-1}$ and as large as $1 \mathrm{~m} \mathrm{~s}^{-1}$. 


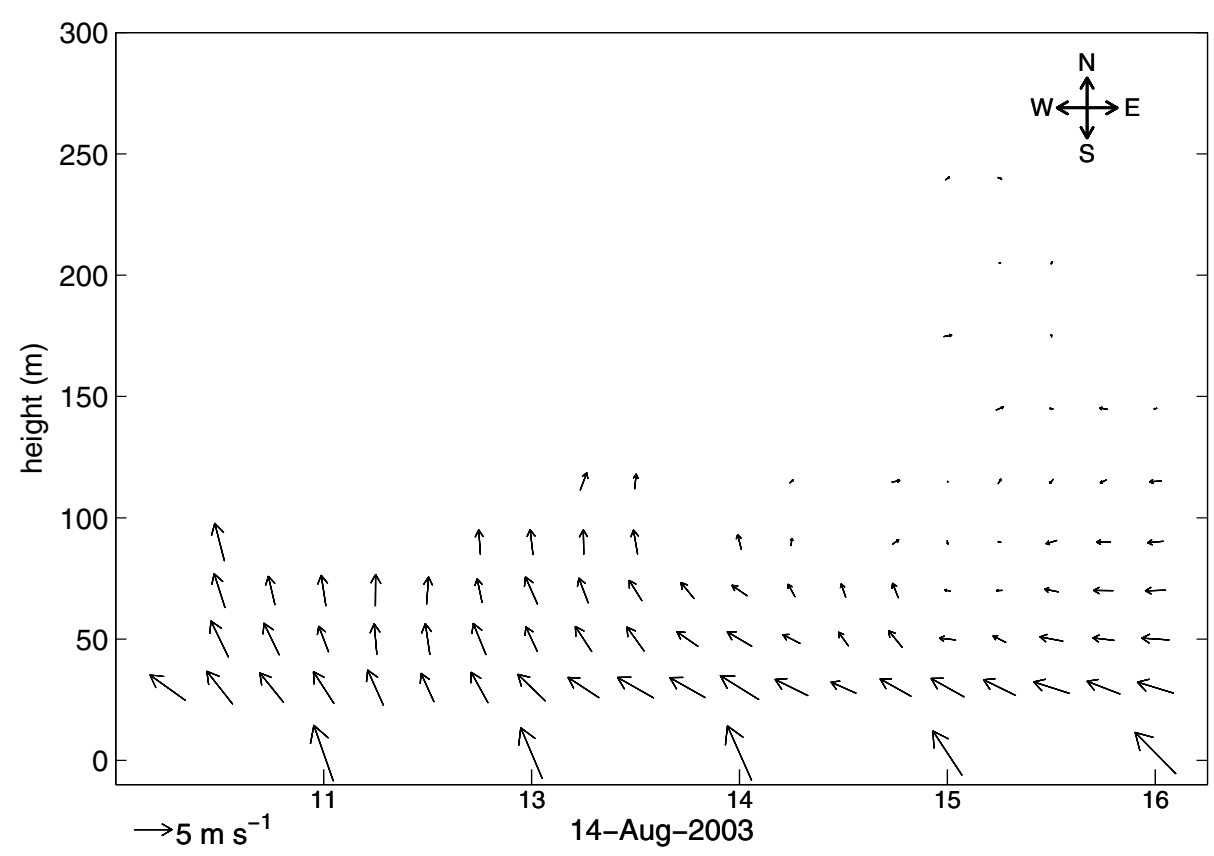

Figure 7. Time series as Fig. 4, but of horizontal wind profiles for 14 August 2003.

The switch from a 5-8 $\mathrm{m} \mathrm{s}^{-1}$ downslope flow to a largely vertical velocity may be related to a hydraulic (or 'katabatic') jump, although there is no direct evidence of a jump from the AWS observations (Fig. 5). Perhaps due to their relatively low temporal resolution (i.e. hourly), or because these are relatively weak downslope flows, any katabatic jump will also be weak. Katabatic jumps have been observed as neardiscontinuities in horizontal wind speed and pressure (e.g. Pettré and André 1991). They have been seen in recent idealized modelling experiments for the Coats Land region by Renfrew (2004) and Yu et al. (2005). Renfrew (2004) found internal gravity waves being triggered towards the foot of the Coats Land continental slope, close to the $\mathrm{C} 2$ site, as the katabatic flow went from weakly supercritical to subcritical in response to cold air building up on the Brunt Ice Shelf and damming the flow. Yu et al. (2005) examined katabatic jumps in detail, finding their location to be a function of the depth and strength of this cold-air pool. Yu et al. found the $\sim 1 \mathrm{hPa}$ pressure changes associated with the katabatic jumps was better explained by a Bernoulli theory analysis than by a simple hydraulic theory analysis. The three-dimensional wind observations in this case are consistent with those modelled in the above studies, and therefore suggest that the strong vertical acceleration may well be associated with a katabatic jump, and thus may be capable of triggering internal gravity waves. Similar patterns of a dramatic ascent following flow cessation are clear on several other days (not shown). A more detailed study of internal gravity waves triggered by katabatic flows is in progress.

\section{(b) A wintertime katabatic flow case}

Horizontal wind profiles from a case of moderate wintertime katabatic flow on 14 August 2003 are illustrated in Fig. 7. Here the strongest observed winds are at the $3 \mathrm{~m}$ (AWS) level. Again there is generally a monotonic decrease in wind speed and an anticlockwise backing with height that is strongest in the surface layer (between 3 and 
$30 \mathrm{~m}$ ). The winds aloft are rather weak compared to the near-surface winds, suggesting a very shallow katabatic flow with a jet maximum between 3 and $30 \mathrm{~m}$.

In Fig. 8 horizontal winds, $\theta, p^{\prime}$, cloud amount and $R H_{\text {ice }}$ are shown for 13-15 August 2003. The surface wind pattern is rather complex, and reflects the presence of a slow-moving low-pressure system to the north in the Weddell Sea, as suggested by the low $p^{\prime}$, the spread of $p^{\prime}$ over the stations, and the sharp rise from a local minima during the 14 August as the low moves past (m.s.l.p. analyses not shown). Its movement is also reflected in a veering of the surface winds and the relatively warm and cloudy conditions at Halley.

During 14 August the winds at C2 are steady and downslope. They are apparently katabatically forced in part as it is relatively cold there; indeed, using data from Table 3 implies $\Delta \theta \approx 9 \mathrm{~K}$ suggesting a substantial katabatic forcing. However, the winds are also influenced by the low-pressure system to the north. At C3 and C4 the flow is more across-slope, indeed somewhat upslope later in the day. It is also relatively warm compared to $\mathrm{C} 2$, such that $\Delta \theta \approx 0 \mathrm{~K}$-there will be no katabatic forcing-and $R H_{\text {ice }}$ is $100 \%$. This suggests that higher on the Coats Land slopes the synoptic-scale flow is dominating. In this case it seems that the downslope flow observed at $\mathrm{C} 2$ is a highly localized response to a local katabatic forcing.

\section{THE VERTICAL STRUCTURE OF PRIMARILY KATABATIC FLOW}

The autonomous Doppler sodar system provides, for the first time, continuous profiling of katabatic flows all the year round from an Antarctic coastal slope. Here an analysis of the vertical structure of these katabatic flows is described. In order to carry out this analysis, a categorization of the observation periods is useful. This has been achieved through a thorough case-by-case assessment of each observation period to determine whether the flow is primarily katabatically or synoptically driven. As discussed recently in a series of observational and modelling papers by various authors (e.g. Parish and Cassano 2001, 2003a,b; Renfrew and Anderson 2002; Van den Broeke et al. 2002) apparently katabatic flow can simply be a synoptically forced flow that is moulded by the topography to be downslope in direction.

Here we have subjectively defined a subset of our observations as "primarily katabatic flows' by examining: (i) surface observations at Halley and Coats Land, (ii) satellite imagery, and (iii) m.s.l.p. analyses, and adapting criteria put forward by Renfrew and Anderson (2002). Observational periods were categorized as being primarily katabatically driven if there were: essentially clear skies (low amounts of cloud observed at Halley and clear satellite imagery); little influence from synoptic-scale weather systems (small $p^{\prime}$ differences and changes at the AWS stations; and an area of weak pressure gradients in the analyses); and a significant potential-temperature deficit (determined from near-surface AWS and free-atmosphere radiosonde observations-as illustrated in the previous section). The primarily katabatic flow periods make a subset of 16 days and 805 soundings from the 28 days and 1626 soundings listed in Table 3 , where they are marked by a superscript $\mathrm{K}$. The rest of this paper focuses on these observations.

Both the observational periods described in the previous section were primarily katabatic flows; as an illustration of the vertical structure, Fig. 9 shows wind speed, wind direction and vertical velocity $(w)$ against height, plus downslope horizontal velocity $(u)$ versus across-slope horizontal velocity $(v)$ for hourly observations combined from the Doppler sodar and AWS on 23 February 2002 (the same period as Figs. 4 and 6). The classic elevated jet shape associated with katabatic flows is clear in a number of the wind speed profiles, but certainly not all. In these the jet maximum is at the lowest 

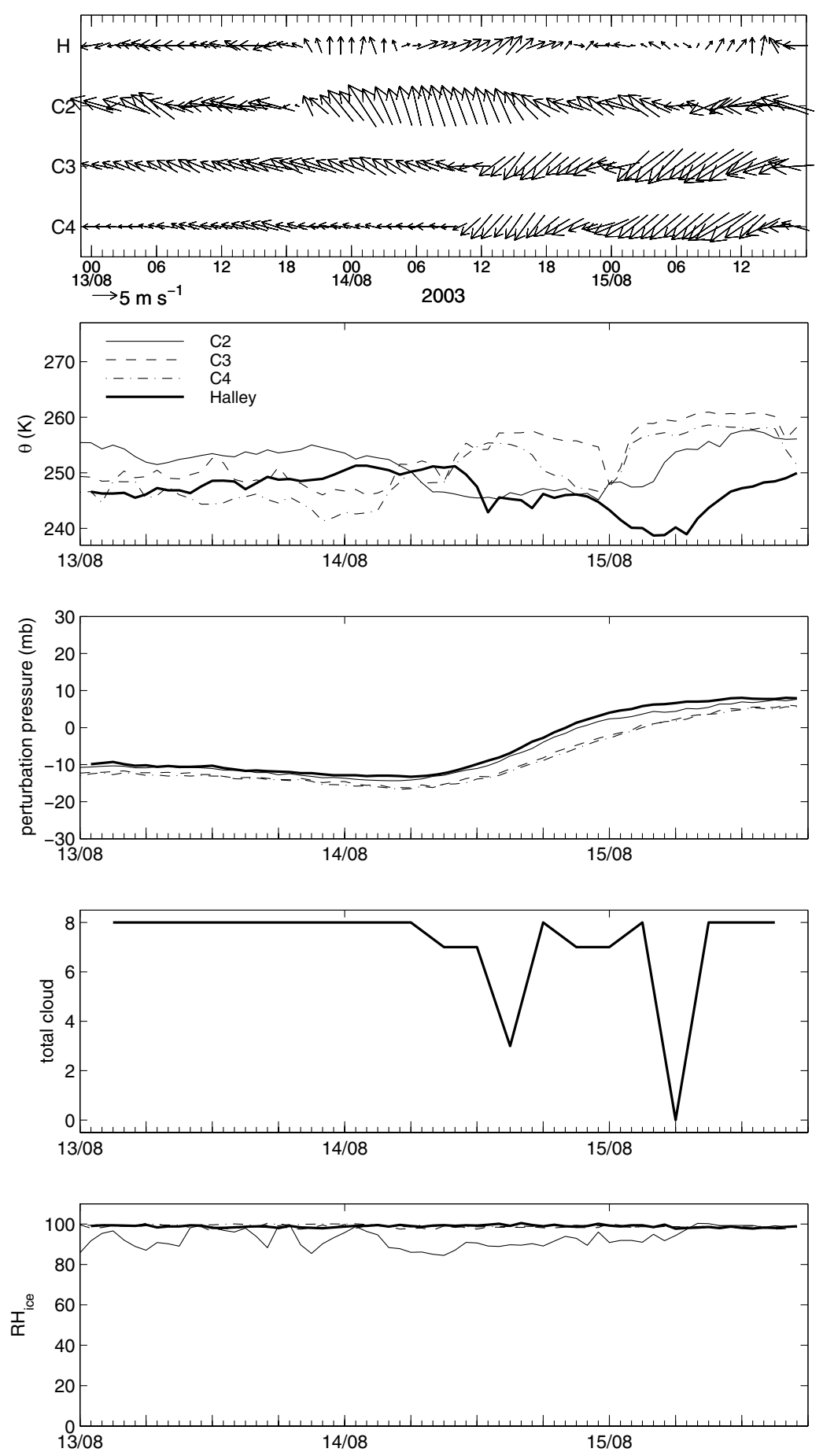

Figure 8. Time series as Fig. 5, but for 13-15 August 2003. 

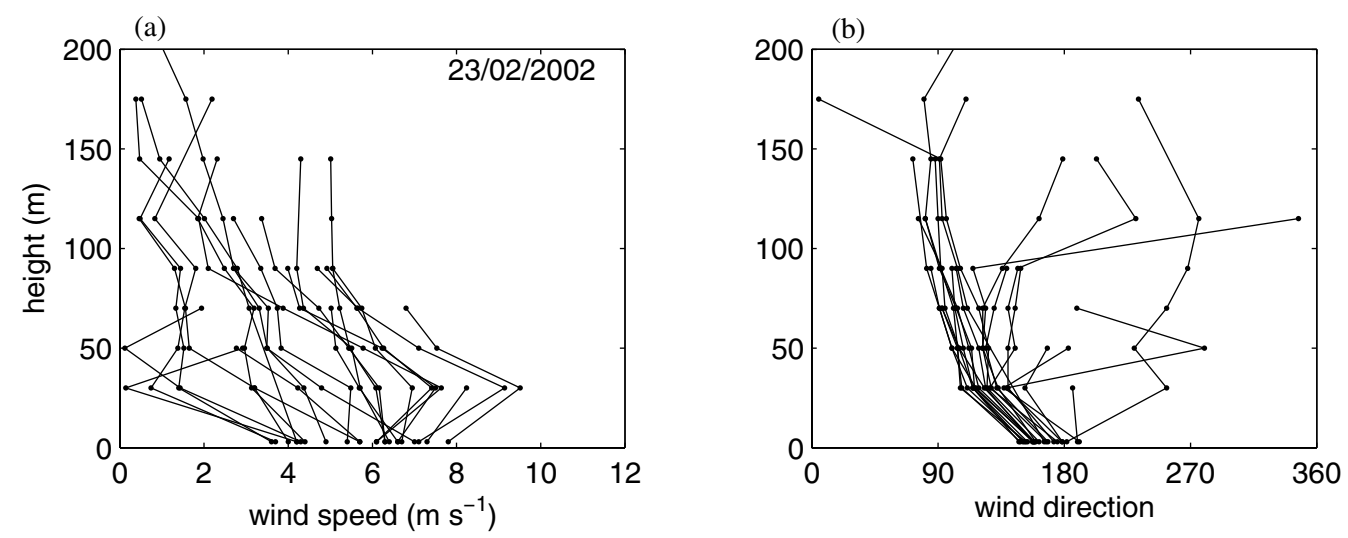

(c)
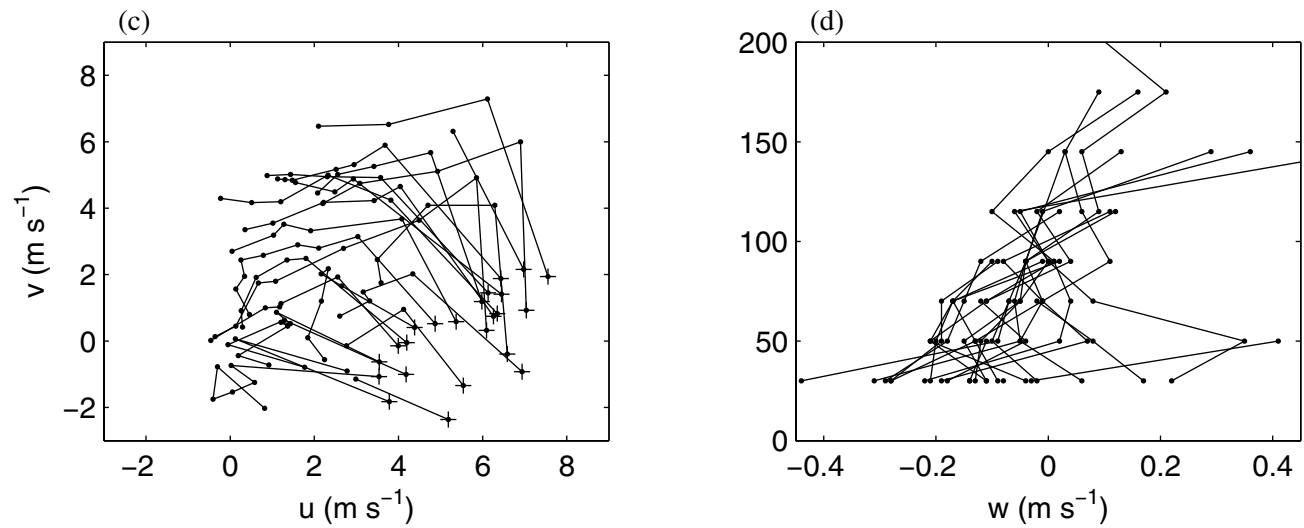

Figure 9. Hourly wind profiles from 23 February 2002 from the combined Doppler sodar and automatic weather station observations south of Halley. Shown are: (a) wind speed and (b) wind direction against height; (c) downslope horizontal velocity $(u)$ against across-slope horizontal velocity $(v)$; and (d) vertical velocity $(w)$ against height. In (c) the lowest-altitude observation is marked with a + sign.

Doppler sodar observation, in this case $30 \mathrm{~m}$. At other times the maximum wind speed that is observed is at the AWS height. Referring back to Fig. 4, one can see that many of these profiles are during the afternoon, when the katabatic flow aloft has ceased but there is still a very shallow downslope wind. The profile of wind direction with height is remarkable consistent through the day, despite the changes in wind speed. There is backing of about $40-60^{\circ}$ between the observations at 3 and $30 \mathrm{~m}$ that continues through the boundary layer and is a result of weakening frictional effects with height. Figure 9(d) shows that for most profiles the strongest descent is in the lowest layers, typically $-0.2 \mathrm{~m} \mathrm{~s}^{-1}$, although profiles with ascent are also evident.

For each profile we calculated the observed maximum wind speed $\left(U_{\max }\right)$ and the height at which this occurs $\left(z_{\max }\right)$. For katabatic flows following the classic shape of an elevated low-level jet, the jet maximum would have speed $U_{\max }$ at a height $z_{\max }$. However, Fig. 9 makes it clear that, in this case, the jet profile is only coarsely resolved by the Doppler sodar and AWS. The jet changes rapidly over the lowest $\sim 100 \mathrm{~m}$ and, given that the Doppler sodar employs volume-averaging over layers of 10-20 m thickness, this means some detail is unresolved; furthermore, at times the jet maximum appears to fall in the gap between 3 and $30 \mathrm{~m}$, i.e. between the AWS and the lowest 


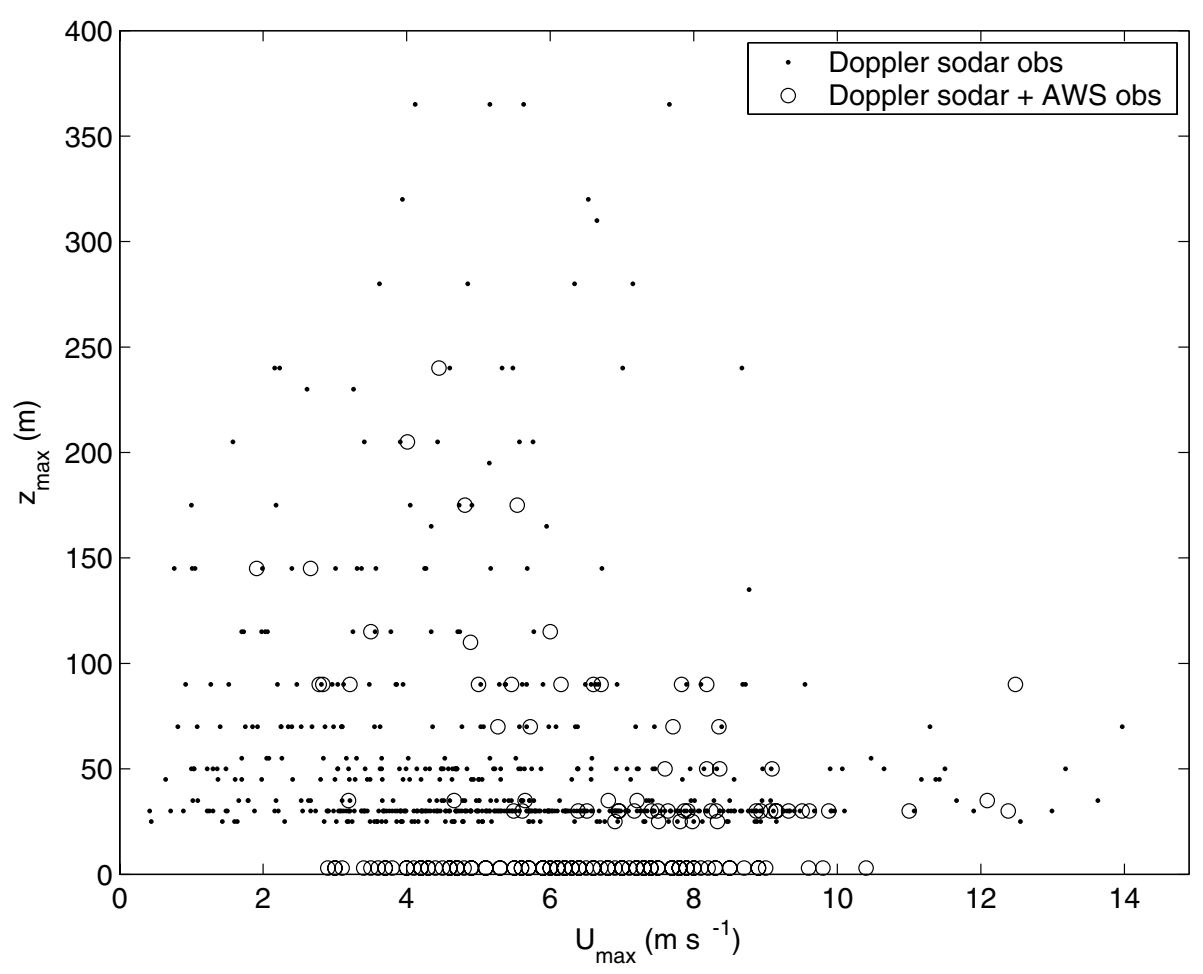

Figure 10. Scatter plot of maximum wind speed $\left(U_{\max }\right)$ versus its height $\left(z_{\max }\right)$ for all the wind profiles measured over the slope south of Halley, where the flow is categorized as primarily katabatically driven (805 profiles). Maxima determined from the Doppler sodar data only are marked by dots, while maxima from profiles where the automatic weather station data are included (a subset of 188 profiles) are marked by open circles.

Doppler sodar range gate (20-40 $\mathrm{m}$ for this period). The flow structure is captured more accurately for observing periods with the higher-resolution Doppler sodar setting (cf. Table 3), however, as mentioned earlier these periods compromise on range. These resolution and observing gap constraints are a limitation to this dataset.

Figure 10 shows $U_{\max }$ versus $z_{\max }$ for all profiles in the primarily katabatic flow category. It is clear that $z_{\max }$ is frequently in the range $3-50 \mathrm{~m}$ for a range of $U_{\max }$ values, which is consistent with the picture of an archetypal low-level jet. The greatest values of $U_{\max }\left(>10 \mathrm{~m} \mathrm{~s}^{-1}\right)$ usually have $z_{\max }$ between 25 and $60 \mathrm{~m}$, on average $\sim 40 \mathrm{~m}$. For the majority of katabatic flow profiles, $z_{\max }$ ranges between 3 to $80 \mathrm{~m}$. Although there are many observations with $z_{\max }$ at higher altitudes, these seem to vary in both height and wind-speed, suggesting no persistent vertical structure with these characteristics. Observations where $z_{\max }=3 \mathrm{~m}$ seem to be limited such that $U_{\max }$ is between 3 and $9 \mathrm{~m} \mathrm{~s}^{-1}$. Profiles where $U_{\max }<3 \mathrm{~m} \mathrm{~s}^{-1}$, i.e. when the entire boundary layer is quiescent, tend to have $z_{\max }$ spread throughout the vertical range; while profiles with $U_{\max }>9 \mathrm{~m} \mathrm{~s}^{-1}$ tend to have $z_{\max }$ confined to $25-60 \mathrm{~m}$, as mentioned above.

Standard surface-layer theory would suggest that when $z_{\max }=3 \mathrm{~m}$, in reality the highest wind speed is probably somewhere in between $3 \mathrm{~m}$ and the height of the lowest Doppler sodar level for that case (i.e. 20-30 m or 20-40 m, depending on the sodar setting). In other words, the jet maximum falls in the gap with no observations in our vertical profiles. This is born out by the fact that when $z_{\max }=3 \mathrm{~m}$, over $50 \%$ of the 
associated profiles have their second highest wind speed at the lowest Doppler sodar level; while the remainder have their second highest wind speed spread throughout the vertical range.

The same plots for subsets of the primarily katabatic flows from winter (AprilSeptember; 230 profiles) and summer (October-March; 575 profiles) have also been examined (not shown). All the strongest low-level jets $\left(>10 \mathrm{~m} \mathrm{~s}^{-1}\right.$ ) occur in winter, and $95 \%$ of all winter $z_{\max }$ values are below $100 \mathrm{~m}$; by contrast the summer values span the vertical range (see Fig. 10). In winter when $z_{\max }=3 \mathrm{~m}, U_{\max }$ is concentrated between 6 and $9 \mathrm{~m} \mathrm{~s}^{-1}$, suggesting that for these very shallow katabatic flows there is a threshold wind speed which wintertime katabatic flows generally attain.

To illustrate mean, or archetypal, katabatic wind profiles the primarily katabatic flow observations have been divided into different flow strengths using their maximum wind speed $\left(U_{\max }\right)$. Profiles of the mean and the mean plus and minus one standard deviation for each flow strength are illustrated in Fig. 11. The profiles have been binned into weak, moderate and strong flows: $0 \leq U_{\max } \leq 4 \mathrm{~m} \mathrm{~s}^{-1}$ (solid line with dots); $4<U_{\max } \leq 8 \mathrm{~m} \mathrm{~s}^{-1}$ (dashed line); and $U_{\max }>8 \mathrm{~m} \mathrm{~s}^{-1}$ (solid line), respectively. The bins contain 198, 436 and 109 Doppler sodar profiles and 19, 135 and 34 AWS observations, respectively. The Doppler sodar observations are linearly interpolated onto a $5 \mathrm{~m}$ resolution vertical grid to allow for the different sodar settings, and then averaged for each height. If less than $10 \%$ of the possible observations are available at that height, then an average is not calculated. This quality-control check is to stop a few profiles dominating the average and, effectively, acts to limit the range of the mean profilesas is apparent in Fig. 11. At a height of $3 \mathrm{~m}$ the mean and mean plus and minus one standard deviation of each bin for the AWS data are plotted. Many fewer observations make up these values (188 compared to 805) due to the hourly temporal resolution of the AWS compared to the 15-minute resolution of the Doppler sodar. In including these data on the same plots we are, in essence, interpolating the AWS data in time. Note, mean profiles of the matched Doppler sodar and AWS data only, were also examined and these are qualitatively similar to those of Fig. 11, suggesting the combination of the Doppler sodar only and the spliced profiles does not distort the illustrated profiles. However, the $3 \mathrm{~m}$ values are plotted as a separate point to illustrate the gap in observations between the AWS and the lowest Doppler sodar range gate.

The mean katabatic flow profiles show systematic differences for the different flow strengths. The weak flows $\left(0 \leq U_{\max } \leq 4 \mathrm{~m} \mathrm{~s}^{-1}\right)$ have a wind speed that is approximately constant with height. There is, on average, a backing in the wind direction with height, the flow being more downslope nearer the surface.

The moderate flows $\left(4<U_{\max } \leq 8 \mathrm{~m} \mathrm{~s}^{-1}\right)$ have a monotonically decreasing wind speed with height, with little evidence of a low-level jet. However, the AWS observations are, on average, higher than the lowest Doppler sodar-level observations. Examining individual profiles (e.g. Figs. 4, 7 and 9) we see that this reflects an averaging over times when $z_{\max } \geq 25 \mathrm{~m}$ (and there is a resolved low-level jet), and when $z_{\max }=3 \mathrm{~m}$ and the flow is weak aloft but maintains a certain minimum speed near the surface (around $4 \mathrm{~m} \mathrm{~s}^{-1}$ in the case illustrated in Fig. 9). This suggests that on average there is a windspeed maximum somewhere between 3 and $25 \mathrm{~m}$, i.e. a very shallow low-level jet, which unfortunately falls in the gap in observations between the AWS and the Doppler sodar. This interpretation is corroborated by summertime observations of weak to moderate katabatic flows on the Breidamerkurjökull glacier, Iceland, by Parmhed et al. (2004). In their mast and balloon profiles the height of observed low-level wind maxima ranged from 2.5 to $13.0 \mathrm{~m}$, with jet wind speeds ranging from 3.3 to $10.1 \mathrm{~m} \mathrm{~s}^{-1}$. Motivated by individual profile observations (e.g. Fig. 9) and other studies (e.g. Parmhed et al. 2004; 

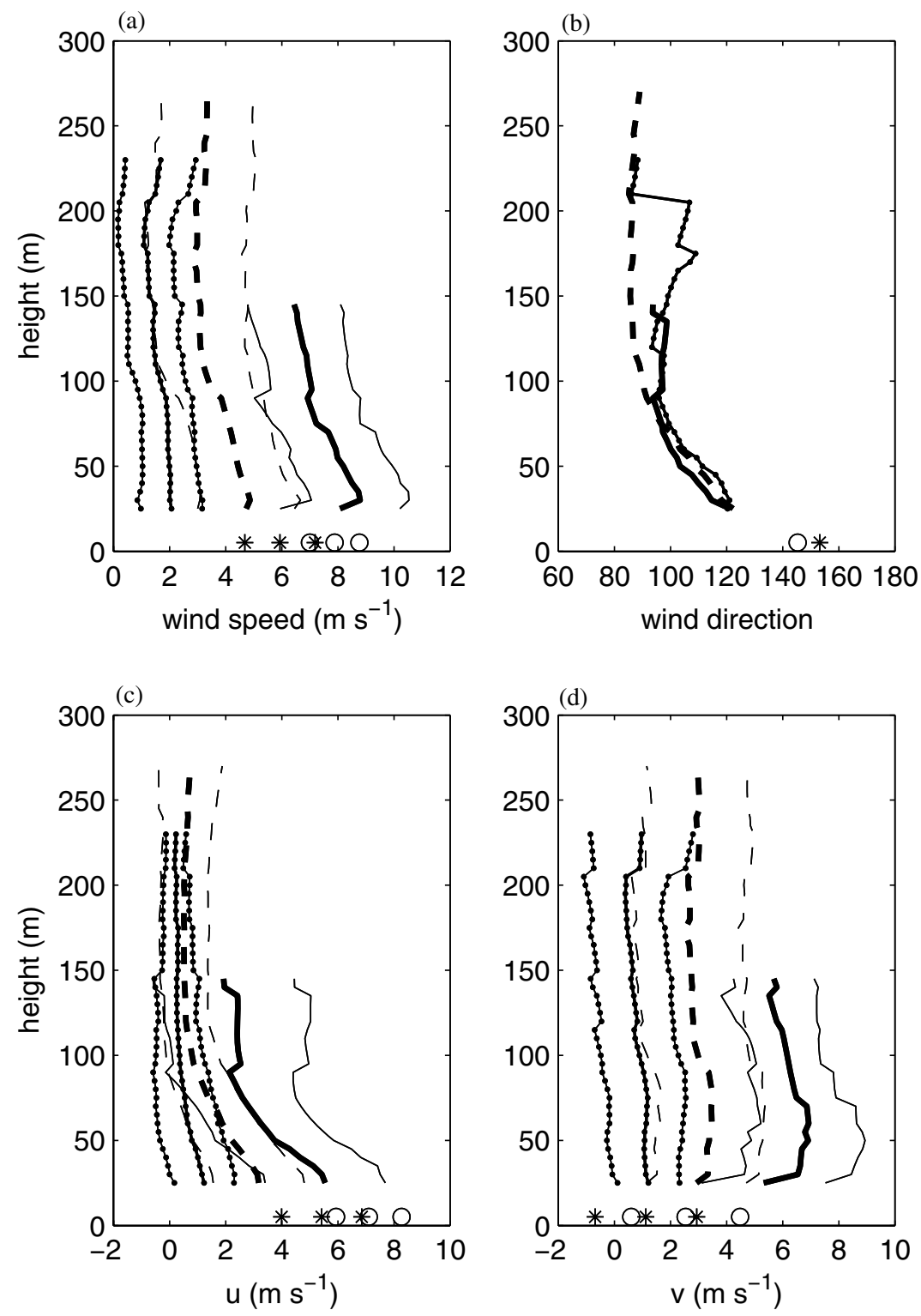

Figure 11. Wind profiles for primarily katabatically driven flows over the slope south of Halley, showing lines for the mean, and the mean plus and minus one standard deviation: (a) wind speed, (b) vector-mean wind direction (mean profiles only for clarity), (c) downslope horizontal velocity $(u)$, and (d) across-slope horizontal velocity $(v)$. The data have been binned into weak, moderate and strong flows: $0 \leq U_{\max } \leq 4 \mathrm{~m} \mathrm{~s}^{-1}$ (solid line with dots); $4<U_{\max } \leq 8 \mathrm{~m} \mathrm{~s}^{-1}$ (dashed lines and stars) and $U_{\max }>8 \mathrm{~m} \mathrm{~s}^{-1}$ (solid lines and open circles), respectively, where $U_{\max }$ is the observed maximum wind speed. The automatic weather station data for each bin have been plotted at the $3 \mathrm{~m}$ level.

Haiden and Whiteman 2005), we suggest that the jet maximum is likely to be at most $\sim 1 \mathrm{~m} \mathrm{~s}^{-1}$ stronger than that measured at $3 \mathrm{~m}$. The mean plus and minus one standard deviation profiles closely mimic the shape of the mean profile, suggesting that there is little change in variability with height (the standard deviation is around $2 \mathrm{~m} \mathrm{~s}^{-1}$ at all levels). In other words, these katabatic flows consistently look like the illustrated mean profile. There is a backing in the wind direction with height: at the AWS level the flow 
is close to downslope $\left(\sim 165^{\circ}\right)$, backing to approximately easterly by $150 \mathrm{~m}$ above the surface.

The strongest flows $\left(U_{\max }>8 \mathrm{~m} \mathrm{~s}^{-1}\right)$ illustrated in Fig. 11 are better resolved by our observing system. The mean wind speed profile has a pronounced low-level jet at $30-35 \mathrm{~m}$. Above the jet maximum the wind speed falls away approximately linearly; while below the jet maximum the mean AWS observation is only $\sim 1 \mathrm{~m} \mathrm{~s}^{-1}$ below the jet maximum value. This suggests that, on average, there is a layer of approximately constant wind speeds between 3 and $25 \mathrm{~m}$. However, individual profiles (e.g. Fig. 9 and similar figures for other days) suggest that sometimes this is the case, but at other times the jet has a more pronounced profile (illustrated by the mean plus one-standarddeviation curve) or is strong and shallow. The wind direction is somewhat more crossslope for these stronger flows compared to the moderate strength flows, reflecting greater Coriolis and frictional forces as a result of the higher wind speeds.

The mean wind profiles illustrate that for strong winds the katabatic flow clearly has a well-defined low-level jet. However, for the moderate winds the mean profile appears to comprise resolved low-level jets and poorly resolved low-level jets suggested by a maximum at the level of the AWS. The mean AWS values are higher than one might expect from looking at individual profiles, because there appears always to be a downslope flow at this height during these primarily katabatically driven periods. In contrast, aloft the katabatic flow can fade away to near-calm conditions (e.g. Fig. 4).

Panels of downslope $(u)$ and cross-slope $(v)$ velocities are also included in Fig. 11. It can be inferred that a low-level maximum in $u$ exists between 3 and $25 \mathrm{~m}$ for both the moderate and strong flows. There is a steep increase in $v$ with height between 3 and $30-40 \mathrm{~m}$. Above that $v$ slowly decreases with height, or is approximately constant, for the weak and moderate flows; it has a more distinctive diffuse jet structure for the strong flows. It is worth noting that for the weak and moderate mean profiles $u$ tends to an approximately constant value of $0-1 \mathrm{~m} \mathrm{~s}^{-1}$ with height. In this sense, one can state that these katabatic flows directly influence only the lowest $\sim 150 \mathrm{~m}$ of the atmosphere. There are insufficient observations to comment on this for the strong-flow category.

Normalized mean profiles, for example $U / U_{\max }$ versus $z / z_{\max }$, were also calculated (not shown). It was found that binning by $U_{\max }$ (as above) the profiles were not selfsimilar; rather, profiles with a high $U_{\max }$ had a broader jet structure, while profiles with a low $U_{\max }$ had a more tightly confined jet structure.

Renfrew (2004) details idealized numerical simulations of katabatic flows over Coats Land using a non-hydrostatic numerical weather prediction model. The simulations are initialized using climatological atmospheric and surface temperatures, and at rest; in other words, the 'background' synoptic-scale flow is assumed to be zero. Further details of the model set-up can be found in Renfrew (2004). Some details particularly pertinent to these katabatic flow simulations are: a model of resolution $2 \mathrm{~km}$ by $2 \mathrm{~km}$ by $5 \mathrm{~m}$ (with stretching in the vertical), a surface-layer scheme following Louis (1979) and Cassano et al. (2001), and a prognostic turbulence scheme for diffusion in the vertical. In the simulations radiative forcing leads to a cooling and the development of a quasi-steady downslope 'pure' katabatic flow. Figure 12 shows soundings at 12, 24, 36 and $48 \mathrm{~h}$ at the $\mathrm{C} 2$ site (the location of the Doppler sodar) from the control simulation described in Renfrew (2004). The dots in the $48 \mathrm{~h}$ sounding illustrate the model's vertical levels. The potential-temperature deficit is around $15 \mathrm{~K}$, the maximum wind speed $\sim 7 \mathrm{~m} \mathrm{~s}^{-1}$ and the low-level jet is around $30 \mathrm{~m}$ above the model surface. Overlaid are mean and mean plus and minus one-standard-deviation profiles of a subset of the primarily katabatic flow observations where: $6<U_{\max } \leq 8 \mathrm{~m} \mathrm{~s}^{-1}$ and $20 \leq z_{\max } \leq 60 \mathrm{~m}$ (106 profiles). This subset is chosen so that the wind speed and height of the observed 

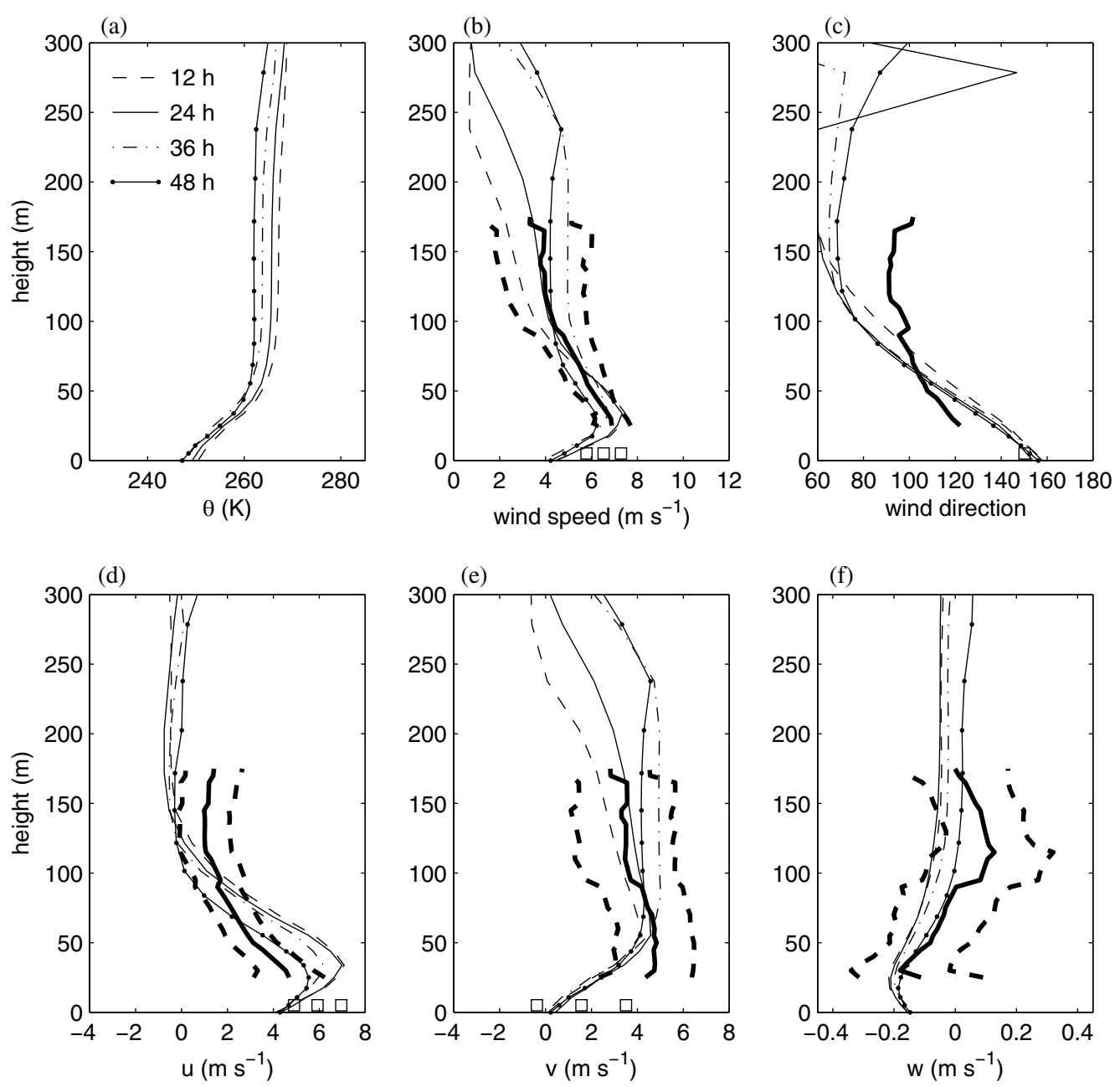

Figure 12. Numerical model soundings at the automatic weather station (AWS) C2 south of Halley for simulation times 12, 24, 36 and $48 \mathrm{~h}$ as indicated, of: (a) potential temperature $(\theta)$, (b) wind speed, (c) wind direction, (d) downslope horizontal velocity $(u),(\mathrm{e})$ across-slope horizontal velocity $(v)$, and (f) vertical velocity $(w)$. Overlaid bold lines show the mean (full line), and mean plus and minus one-standard-deviation (dashed lines) wind profiles for a subset of the primarily katabatic flows with $6<U_{\max } \leq 8 \mathrm{~m} \mathrm{~s}^{-1}$ and $20 \leq z_{\max } \leq 60 \mathrm{~m}$, where $U_{\max }$ is the measured wind speed maximum, and $z_{\max }$ the height of the maximum wind. Data from the AWS (at $3 \mathrm{~m}$ ) have been plotted as squares.

low-level jet matches that of the control simulation, and hence other features of the simulated katabatic flow can be meaningfully compared to the observations.

The simulated wind speed profiles generally compare well with the observations. Over time in the simulation there is a general broadening of the low-level jet, as momentum is mixed upwards. The soundings at 36 and $48 \mathrm{~h}$ correspond most closely in shape to the mean profile, although the more focused jet shapes at 12 and $24 \mathrm{~h}$ are well within the range that is observed. In contrast, the simulated $3 \mathrm{~m}$ wind speeds are all well below the observations, i.e. the simulation does not capture the rapid increase in wind speed near the surface. This problem was also noted in Renfrew (2004), where comparisons with mean AWS observations were made. In that study it was suggested that either the model's surface-layer parametrization was at fault or there was a sampling 
problem in the way that the average wind speeds were calculated. The comparison in Fig. 12 rules out any such sampling problems. Indeed, it is clear from comparing the model profiles to those in Figs. 4, 7, 9, 11 and 12 that the katabatic jet often reaches its maximum value over these lowest few metres, a feature not captured by this simulation, nor indeed any others carried out by Renfrew (2004), e.g. those where the ratio of the momentum to heat diffusion coefficients was tuned. These results confirm that further work on parametrizing the model's surface layer for stable conditions is required.

The simulated wind direction generally compares well with the observed wind direction, especially at $3 \mathrm{~m}$. The simulated profiles back more steeply than the observations - probably a reflection of the fact that on average there is a light background wind in the observations (easterly aloft, more south-easterly at the surface) which is not in the model. This missing background wind also affects the simulated $u$ and $v$ components, which are otherwise generally well-simulated. There are some differences aloft where the model simulates $u$ tending to zero, while in reality an easterly background wind will project approximately equally onto the down-slope and crossslope directions. The poor simulation over the first few model levels is manifest as an underestimate of magnitudes of both $u$ and $v$ at $3 \mathrm{~m}$. Indeed the simulated $u$ jet is too high and strong, while the simulated $v$ flow does not increase quickly enough over the lowest $30 \mathrm{~m}$, but corresponds well from $\sim 50 \mathrm{~m}$ upwards.

The simulated descent into the katabatic layer compares well with that observedthe minimum values are about the correct height and magnitude. There is clearly more variability in the observations, with the mean plus one-standard-deviation profile largely positive. This reflects both the turbulent nature of katabatic flows and the dramatic ascent that occurs upon the cessation of katabatic flows (e.g. Fig. 6).

In summary, the simulated pure katabatic flows generally compare well to the mean primarily katabatic flow observations; the main difference is that the model winds are too weak over the first few model levels. The overall structure is well modelled, if one allows for a residual background flow in the observations that is not included in the model simulation.

\section{CONCLUSIONS}

An analysis of subjectively determined katabatic flows in Coats Land, Antarctica, making use of vertical wind profiles from an autonomous Doppler sodar system has highlighted a number of interesting features. There is a systematic change in the shape of the low-level katabatic jet with wind speed. On average, stronger katabatic flows, with wind speed maxima of typically $8-10 \mathrm{~m} \mathrm{~s}^{-1}$, are deeper with a jet maximum at 20-60 m altitude; moderate katabatic flows, with wind speed maxima of typically 4-8 $\mathrm{m} \mathrm{s}^{-1}$, are shallower with a jet maximum more often between 3 and $30 \mathrm{~m}$. The strongest katabatic flows have a greater cross-slope component, consistent with a greater Coriolis force and frictional drag. For all katabatic wind profiles there is a backing in wind direction with height over the lowest $\sim 100 \mathrm{~m}$, consistent with a frictional forcing at the surface.

During summer there is a clear diurnal signature in the katabatic flow at all heights. It is more pronounced at $20 \mathrm{~m}$ and above, where the flow often ceases entirely, whereas at the surface there always appears to be some weak $\left(2-4 \mathrm{~m} \mathrm{~s}^{-1}\right)$ katabatic flow. A dramatic deceleration of the katabatic flow is followed by strong vertical accelerationwith vertical velocities reaching $0.25-1 \mathrm{~m} \mathrm{~s}^{-1}$. Such cessation events may lead to katabatic jumps, analogous to hydraulic jumps, as the flow changes from supercritical to 
subcritical down the slope; this was seen in recent non-hydrostatic numerical modelling studies of katabatic flow in Coats Land (Renfrew 2004; Yu et al. 2005).

Simulated wind profiles from the Renfrew (2004) modelling study compare well to mean profiles of a conditionally sampled subset of the katabatic flow observations. The structure and direction of the observed flows are well simulated, especially if one allows for a weak background flow in the observations that is not present in the simulations. The one significant difference is that the model does not capture the rapid increase in wind speed over the lowest $\sim 10 \mathrm{~m}$, i.e. the wind speed is too weak for the first few model levels.

\section{ACKNOWLEDGEMENTS}

We thank Russ Ladkin, Cathy Moore, Elaine Cowie, Annette Faux, and a number of other Halley Research Station wintering personnel for their part in operating the autonomous Doppler sodar system. We also thank John King for useful comments on this work and support through the Doppler Sodar project; and two anonymous reviewers for their helpful suggestions.

Anderson, P. S., Ladkin, R. and Renfrew, I. A.

Ball, F. K.

BAS

Bintanja, R.

Bromwich, D. H.

Bromwich, D. H. and Liu, Z.

Cassano, J. J., Parish, T. R. and King, J. C.

Gallée, H. and Pettré, P.

Gallée, H. and Schayes, G.

Gallée, H., Pettré, P. and

Schayes, G.

Haiden, T. and Whiteman, C. D.

Heinemann, G.

King, J. C.

King, J. C. and Anderson, P. S.
2005

1956

1960

1993

$2000 \mathrm{a}$

$2000 b$

1989

1996

2001

1998

1992

1996

2005

1999

1999

\section{REFERENCES}

An autonomous Doppler sodar wind profiling system. J. Atmos. Oceanic Technol., 22, 1309-1325

The theory of strong katabatic winds. Aust. J. Phys., 9, 373-386

Winds on the ice slopes of Antarctica. Pp. 9-16 in Antarctic meteorology. Pergamon Press, Oxford, UK

Antarctic Digital Database user's guide and reference manual. British Antarctic Survey, Scientific Committee on Antarctic Research, Cambridge, UK

Mesoscale meteorological conditions in Dronning Maud Land, Antarctica, during summer: A qualitative analysis of forcing mechanisms. J. Appl. Meteorol., 39, 2348-2370

Mesoscale meteorological conditions in Dronning Maud Land, Antarctica, during summer: The momentum budget of the boundary layer. Antarctic Sci., 12, 229-242

An extraordinary katabatic wind regime at Terra Nova Bay, Antarctica. Mon. Weather Rev., 117, 688-695

An observational study of the katabatic wind confluence zone near Siple Coast, West Antarctica. Mon. Weather Rev., 124, $462-467$

Evaluation of turbulent surface flux parameterizations for the stable surface layer over Halley, Antarctica. Mon. Weather Rev., 129, 26-46

Dynamical constraints on katabatic wind cessation in Adelie Land, Antarctica. J. Atmos. Sci., 55, 1755-1770

Dynamical aspects of katabatic wind evolution in the Antarctic coastal zone. Boundary-Layer Meteorol., 59, 141-161

Sudden cessation of katabatic winds in Adélie Land, Antarctica. J. Appl. Meteorol., 35, 1147-1152

Katabatic flow mechanisms on a low-angle slope. J. Appl. Meteorol., 44, 113-126

The KABEG 97 field experiment: An aircraft-based study of katabatic wind dynamics over the Greenland Ice Sheet. Boundary-Layer Meteorol., 93, 75-116

Modelling and observations of the katabatic flow dynamics over Greenland. Tellus, 54A, 542-554

Control of near-surface winds over an Antarctic ice shelf. J. Geophys. Res., 98, 12949-12954

A humidity climatology for Halley, Antarctica, based on frostpoint hygrometer measurements. Antarctic Sci., 11, 100-104 
King, J. C., Varley, M. J. and Lachlan-Cope, T. A.

Louis, J. F.

Lettau, H. H. and Mahrt, L. Schwerdtfeger, W.

Mather, K. B. and Miller, G. S.

Meesters, A. G. C. A., Bink, N. J., Henneken, E. A. C., Vugts, H. F. and Cannemeijer, F.

Ohata, T., Kobayashi, S., Ishikawa, $\mathrm{N}$. and Kawaguchi, S.

Parish, T. R.

Parish, T. R. and Bromwich, D. H.

Parish, T. R. and Cassano, J. J.

Parmhed, O., Oerlemanns, J. and Grisogono, B.

Pettré, P. and André, J.-C.

Renfrew, I. A.

Renfrew, I. A. and Anderson, P. S.

Sorbjan, Z., Kodama, Y. and Wendler, G.

Stearns, C. R. and Wendler, G.

Van den Broeke, M. R., Duynkerke, P. G. and Oerlemans, J.

Van den Broeke, M. R., Van Lipzig, N. P. M. and Van Meijgaard, E.

Wendler, G., André, J. C., Pettré, P., Gosink, J. and Parish, T.

Yu, Y., Cai, X., King, J. C. and Renfrew, I. A.
1998 Using satellite thermal infrared imagery to study boundary layer structure in an Antarctic katabatic wind region. Int. J. Remote Sensing, 19, 3335-3348

1979 A parametric model of vertical eddy fluxes in the atmosphere. Boundary-Layer Meteorol., 17, 187-202

1967 Dynamics of the surface wind regime over the interior of Antarctica. Antarctic J. of US, 2, 155-158

1982 Momentum balance of gravity flows. J. Atmos. Sci., 39, 27012711

1967 'Notes on topographic factors affecting the surface wind in Antarctica, with special references to katabatic winds; and bibliography'. Technical report (Grant no. GA-900). University of Alaska, Fairbanks, USA

1997 Katabatic wind profiles over the Greenland ice sheet: Observations and modelling. Boundary-layer Meteorol., 85, 475-496

1985 Structure of the katabatic winds at Mizuho Station, east Antarctica. J. Geophysical Res., 90, 10651-10658

1988 Surface winds over the Antarctic continent: A review. Rev. Geophys., 26, 169-180

1991 Continental-scale simulation of the Antarctic katabatic wind regime. J. Climate, 4, 135-146

1998 A case study of Antarctic katabatic wind interaction with large-scale forcing. Mon. Weather Rev., 126, 199-209

2001 Forcing of the wintertime Antarctic boundary layer winds from the NCEP/NCAR global reanalysis. J. Appl. Meteorol., 40, $810-821$

2003a The role of katabatic winds on the Antarctic surface wind regime. Mon. Weather Rev., 131, 317-333

2003b Diagnosis of the katabatic wind influence on the wintertime Antarctic surface wind field from numerical simulations. Mon. Weather Rev., 131, 1128-1139

2004 Describing surface fluxes in katabatic flow on Breidamerkurjökull, Iceland. Q. J. R. Meteorol. Soc., 130, $1137-1151$

1991 Surface-pressure change through Loewe's phenomena and katabatic flow jumps: Study of two cases in Adelie Land, Antarctica. J. Atmos. Sci., 48, 557-571

2004 The dynamics of idealized katabatic flow over a moderate slope and ice shelf. Q. J. R. Meteorol. Soc., 130, 1023-1045

2002 The surface climatology of an ordinary katabatic wind regime in Coats Land, Antarctica. Tellus, 54A, 463-484

1986 Observational study of the atmospheric boundary layer over Antarctica. J. Clim. Appl. Meteorol., 25, 641-651

1988 Research results from Antarctic automatic weather stations. Rev. Geophys., 26, 45-61

1994 The observed katabatic flow at the edge of the Greenland ice sheet during GIMEX-91. Global and Planetary Change, 9, 3-15

2002 Momentum budget of the east-Antarctic atmospheric boundary layer: Results of a regional climate model. J. Atmos. Sci., 59, 3117-3129

1993 Katabatic winds in Adélie coast. Pp. 23-46 in Antarctic Research Series, Vol. 61: Antarctic meteorology and climatology studies based on automatic weather stations. Eds. D. H. Bromwich and C. R. Stearns. American Geophysical Union, Washington, USA

2005 Numerical simulations of katabatic jumps in Coats Land, Antarctica. Boundary-Layer Meteorol., 114, 413-437 